\title{
PELAKSANAAN DISINFEKSI DALAM PENCEGAHAN PENULARAN COVID- 19 DAN POTENSI RISIKO TERHADAP KESEHATAN DI INDONESIA
}

\author{
Implementation of Disifection in Prevention of Covid-19 Transmission and Its \\ Potential Health Risk in Indonesia
}

\author{
Athena ${ }^{1}$, Eva Laelasari ${ }^{1}$, Tities Puspita ${ }^{1}$ \\ ${ }^{1}$ Puslitbang UpayaKesehatan Masyarakat, Badan Litbangkes \\ Email: athenafb@yahoo.com
}

Diterima: 28 April 2020; Direvisi: 17 Juni 2020; Disetujui: 25 Juni 2020

\begin{abstract}
When the Covid-19 pandemic was established, various countries made efforts to prevent the transmission of the disease; Indonesia is no exception. One way to break the chain of transmission is to disinfect. This article is a scoping review with the aim of getting an overview of the implementation of disinfection in preventing Covid-19 transmission in public areas and possible health risks posed in several regions in Indonesia. The data/information were collected by searching websites of various ministries/institutions and online media within 3 (three) months, starting from March 2020 (establishment of the Covid-19 pandemic) until May 2020. Data and information collected includes location, procedures, and targets of disinfection, as well as disinfectants used, and their effects on health. Data analysis was performed descriptively. The results showed that disinfection in public areas were conducted in offices, health facilities (hospitals and health centers), housing, shopping centers/malls/market, transportation areas (highways, terminals, bus stops, and vehicles). Disinfection has been carried out by spraying directly on surfaces/objects that are often touched and by spraying in the disinfection booth using irritant disinfectants. It can be concluded that the implementation of disinfection in public areas has the potential to cause health risks. It needs supervision in the implementation of disinfection, socialization and education about potential health risks to the community.
\end{abstract}

Keywords: Disinfection, spraying, disinfection booths, public areas, disinfectants, health risks

\begin{abstract}
ABSTRAK
Saat ditetapkannya status pandemi Covid-19, berbagai negara melakukan upaya pencegahan penularan penyakit tersebut; tidak terkecuali Indonesia. Salah satu cara untuk memutus rantai penularan adalah dengan melakukan disinfeksi. Artikel ini merupakan scoping review dengan tujuan untuk mendapatkan gambaran pelaksanaan disinfeksi dalam pencegahan penularan Covid-19 di area publik dan kemungkinan risiko kesehatan yang ditimbulkan. Cara pengumpulan data/informasi adalah dengan penelusuran website berbagai kementerian/lembaga dan media online dalam kurun 3 (tiga) bulan, yaitu mulai Maret 2020 (penetapan pandemi Covid-19) sampai dengan Mei 2020. Data dan informasi yang dikumpulkan meliputi acuan, lokasi, cara, sasaran disinfeksi, serta disinfektan yang digunakan, dan pengaruhnya terhadap kesehatan. Analisis data dilakukan secara deskriptif. Hasil menunjukkan bahwa disinfeksi di area publik, di perkantoran, fasilitas kesehatan (rumah sakit dan puskesmas), perumahan, pusat perbelanjaan/mall/pasar, dan area transportasi (jalan raya, terminal, halte, dan kendaraan) dilakukan dengan cara penyemprotan langsung terhadap permukaan/benda yang sering disentuh dan di dalam bilik disinfeksi, menggunakan disinfektan yang bersifat iritatif. Pelaksanaannya disinfeksi di beberapa area publik masih belum sesuai dengan Protokol/Pedoman Disinfeksi dalam Pencegahan Penularan Covid-19 sehingga berportensi menimbulkan risiko kesehatan. Dapat disimpulkan bahwa pelaksanaan disinfeksi di area publik berpotensi menimbulkan risiko kesehatan. Perlu adanya pengawasan dalam pelaksanaan disinfeksi dan sosialisasi serta edukasi tentang potensi risiko kesehatan terhadap masyarakat.
\end{abstract}

Kata kunci: Disinfeksi, penyemprotan, bilik disinfeksi, area publik, disinfektan, risiko kesehatan 


\section{PENDAHULUAN}

Saat ini, hampir seluruh negara di dunia terinfeksi virus novel corona SARS$\mathrm{CoV}-2$ atau penyakit Covid-19, tidak terkecuali Indonesia. Menurut Badan Kesehatan Dunia (WHO), setidaknya ada 199 negara dan teritori yang telah terpapar virus yang pertama kali muncul di Wuhan, China (World Health Organization, 2020). Sejak pertengahan Maret, penyebaran virus novel corona di Indonesia mengalami peningkatan. Berdasarkan informasi dari Gugus Tugas Percepatan Penanganan Covid-19, per tanggal 20 Maret 2020 jam 13.00, hasil pemeriksaan menunjukkan sebanyak 369 orang positif, pada tanggal 28 Maret 2020 menjadi 1.155 orang, dan pada tanggal 28 Mei 2020 meningkat tajam menjadi 24.538 orang positif. Dilihat dari tingkat kematian per tanggal 20 Maret 2020, tingkat kematian kasus positif di Indonesia dua kali lipat dibandingkan tingkat kematian di dunia, yaitu mencapai $8,67 \%$, bahkan pada tanggal 18 Maret 2020 telah mendekati 10\%. Akan tetapi, pada 31 Mei 2020 jumlah terkonfirmasi mencapai 26.473 orang dengan prevalensi kematian telah menurun, yaitu sebesar 6,09\% (Gugus Tugas Percepatan Penanganan Covid19, 2020b).

Dilihat dari cara penularannya, transmisi terjadi melalui percikan-percikan (droplet) dari hidung atau mulut seseorang yang terjangkit Covid-19 saat bernafas atau batuk. Percikan tersebut dapat masuk ke dalam tubuh secara langsung yaitu terhirupnya droplet seseorang yang terinfeksi. Penularan tidak langsung terjadi karena jatuhnya percikan dari penderita dan menempel pada permukaan benda di sekitar penderita. Seseorang yang menyentuh benda/permukaan tersebut akan terjangkit apabila menyentuh mata, hidung, atau mulut. Oleh karena itu dalam mencegah penyebarannya, masyarakat dihimbau untuk selalu menjaga agar tidak tertular, diantaranya dengan mencuci tangan dengan benar, menggunakan masker, membatasi aktivitas di luar rumah, menghindari kerumunan, melakukan social distancing diikuti dengan proses belajar, bekerja, dan beribadah di rumah serta melakukan disinfeksi benda/permukaan yang diduga terinfeksi oleh virus corona.
Sejak WHO meningkatkan status Covid-19 secara global menjadi pandemi, pemerintah Indonesia telah berupaya meningkatkan kewaspadaan terutama dalam hal penanganan dan pencegahan penyebaran kasus, dengan menerbitkan Protokol Penanganan Covid-19 untuk berbagai sektor. Hal ini merupakan perwujudan bahwa pemerintah hadir dan siap menghadapi Covid 19. Protokol tersebut tidak hanya berisi panduan bagaimana penanganan penderita yang telah terinfeksi Covid 19, dan menghindari penularan secara langsung; tetapi juga memberi panduan disinfeksi di tempat umum sebagai upaya pencegahan penularan di tempat umum (Gugus Tugas Percepatan Penanganan COVID-19, 2020a, 2020b; Kantor Staf Presiden RI, 2020; Kementerian Kesehatan, 2020b).

Sesuai dengan definisinya, disinfeksi adalah proses pengurangan jumlah mikroorganisme ke tingkat bahaya lebih rendah pada permukaan yang terindikasi kontaminasi oleh mikroorganisme dengan menggunakan bahan (disinfektan) yang dapat berfungsi untuk mengendalikan, mencegah, bahkan menghancurkan mikroorganisme berbahaya (Occupational Safety and Health Branch. Labour Department, 2007). Dengan demikian materialnya harus bersifat destruktif. Dengan intensnya kegiatan disinfeksi yang dilakukan oleh berbagai pihak hampir di semua area publik, kemungkinan akan menimbulkan masalah terhadap lingkungan maupun kesehatan, mengingat bahan yang digunakan pada umumnya bersifat racun. Artikel ini merupakan tinjauan dan analisis deskriptif terhadap pemberitaan, laporan, dan pustaka tentang gambaran pelaksanaan disinfeksi selama pandemi Covid-19 di berbagai area publik di beberapa wilayah di Indonesia dan potensi risiko kesehatan masyarakat akibat pajanan bahan aktif disinfektan.

\section{BAHAN DAN CARA}

Artikel ini merupakan hasil penelusuran pemberitaan, laporan, dan literatur dengan desain scoping review, yaitu mengkaji pelaksanaan disinfeksi selama pandemi Covid-19 dan kemungkinan risiko kesehatan. Data dan informasi yang 
dikumpulkan meliputi acuan terkait disinfeksi dalam pencegahan penularan Covid-19 yang berupa pedoman/panduan, protokol dari berbagai sektor, pelaksanaan disinfeksi selama pandemi Covid-19 di Indonesia,cara dan sasaran disinfeksi di area publik, jenis disinfektan yang digunakan. Sumber informasi berasal dari laporan, dan publikasi hasil-hasil kegiatan dari berbagai pemberitaan dalam berbagai website Kementerian/Lembaga di Indonesia dalam rentang waktu 3 (tiga) bulan, yaitu mulai awal Maret (sejak mulainya pandemi Covid-19) sampai dengan akhir Mei 2020. Informasi tentang pengaruh disinfektan terhadap kesehatan berasal dari berbagai dokumen publikasi, pedoman yang dikeluarkan oleh institusi nasional maupun internasional. Tinjauan ini memiliki keterbatasan, karena publikasi yang tidak diterbitkan secara online menjadi tidak terjaring.
Penelusuran dilakukan dengan cara memasukkan kata kunci sesuai dengan topik kajian, dan strategi pencarian literatur menggabungkan kata kunci dari berbagai kategori (Tabel 1). Analisis data dilakukan secara deskriptif dengan membuat matriks berdasarkan lokasi, cara, dan sasaran disinfeksi, jenis disinfektan yang digunakan dalam disifeksi, serta penggunaan APD oleh petugas penyemprot. Untuk informasi penggunaan APD, hanya dikumpulkan untuk petugas yang melakukan penyemprotan secara langsung; dengan kategori lengkap, jika petugas penyemprot mengenakan pakaian khusus, masker pelindung kepala, goggle, sarung tangan, pelindung kaki (sepatu boot). Memakai APD tidak lengkap, jika petugas penyemprot tidak mengenakan satu atau lebih APD.

Tabel 1. Kategori dan kata kunci dalam melakukan penelusuran

\begin{tabular}{|c|c|}
\hline Informasi & Kata kunci \\
\hline $\begin{array}{l}\text { Acuan disinfeksi dalam pencegahan } \\
\text { penularan Covid-19 }\end{array}$ & $\begin{array}{l}\text { "protokol pencegahan penularan Covid-19", } \\
\text { "pedoman/petunjuk teknis disinfeksi Covid-19", }\end{array}$ \\
\hline $\begin{array}{l}\text { Pelaksanaan disinfeksi } \\
\text { pandemi Covid-19 }\end{array}$ & $\begin{array}{l}\text { "lokasi/tempat disinfeksi", "cara disinfeksi" "bahan } \\
\text { disinfeksi atau disinfektan" "penggunaan APD oleh } \\
\text { petugas disinfeksi" }\end{array}$ \\
\hline $\begin{array}{l}\text { Kemungkinan risiko Kesehatan } \\
\text { akibat pajanan disinfektan }\end{array}$ & "karakteristik disinfektan", "disinfectans hazard" \\
\hline
\end{tabular}

\section{HASIL}

\section{Acuan disinfeksi pencegahan penularan Covid-19}

Sejak merebaknya kasus Covid-19, pemerintah berupaya melakukan penanggulangan dengan mengeluarkan protokol untuk acuan berbagai sektor. Sampai dengan pertengahan April 2020, telah diterbitkan berbagai protokol/pedoman/panduan, di antaranya adalah Protokol Kesehatan, Protokol Komunikasi, Protokol Pengawasan Perbatasan, Protokol Area Pendidikan, dan Protokol Transportasi dan Area Publik (Gugus Tugas Percepatan Penanganan Covid-19 2020a, Kantor Staf Presiden RI 2020), Protokol Disinfeksi (Tim Satgas Covid-19 UGM, 2020), Panduan Pencegahan Penularan Covid-19 di Tempat dan Fasilitas Umum/TFU (Kementerian Kesehatan, 2020b). Di tingkat daerah, Pemerintah Provinsi DKI juga berkomitmen dalam upaya pencegahan penularan Covid-19 dengan menerbitkan Panduan Disinfeksi (Pemprov DKI Jakarta, 2020). Beberapa protokol/panduan memberikan panduan tentang tata cara atau prosedur dalam melakukan disinfeksi untuk mencegah/memutuskan rantai penularan. Tabel berikut adalah rangkuman tentang tata cara melaksanakan disinfeksi berdasarkan acuan tersebut: 
Tabel 2. Tata cara disinfeksi berdasarkan protokol/pedoman pencegahan penularan Covid-19 di Indonesia, 2020

\begin{tabular}{|c|c|c|c|}
\hline Acuan & Lokasi/tempat & Disinfektan & Cara \\
\hline $\begin{array}{l}\text { Protokol Disinfeksi di } \\
\text { Tempat Kerja (Tim Satgas } \\
\text { Covid-19 UGM, 2020) }\end{array}$ & $\begin{array}{l}\text { Tempat kerja } \\
\text { (perkantoran, pusat } \\
\text { perbelanjaan) }\end{array}$ & $\begin{array}{l}\text { Pemutih (bleach), } \\
\text { alkohol 70\%, karbol, } \\
\text { pembersih di rumah } \\
\text { tangga (sabun, } \\
\text { pembersih lantai, } \\
\text { pembersih kaca) }\end{array}$ & $\begin{array}{l}\text { Disemprotkan atau } \\
\text { dengan menggunakan } \\
\text { lap (kain microfiber) }\end{array}$ \\
\hline $\begin{array}{l}\text { Panduan Pencegahan } \\
\text { Penularan Covid-19 di } \\
\text { Tempat dan Fasilitas } \\
\text { Umum/TFU(Kementerian } \\
\text { Kesehatan, 2020b) }\end{array}$ & $\begin{array}{l}\text { Rumah, } \\
\text { area publik (pusat } \\
\text { perbelanjaan, } \\
\text { terminal, pasar, } \\
\text { stasiun, sekolah, } \\
\text { masjid, restoran, } \\
\text { dll). Udara }\end{array}$ & $\begin{array}{l}\text { Pemutih (bleach), } \\
\text { senyawa diamin, } \\
\text { karbol/lysol, } \\
\text { pembersih lantai, } \\
\text { hidrogen peroksida }\end{array}$ & $\begin{array}{l}\text { Permukaan } \quad \text { benda: } \\
\text { disemprotkan atau } \\
\text { dengan menggunakan } \\
\text { lap (kain microfiber). } \\
\text { Udara:dry r mist } \\
\text { disinfection. }\end{array}$ \\
\hline $\begin{array}{l}\text { Panduan Disinfeksi } \\
\text { (Pemprov DKI Jakarta, } \\
\text { 2020) }\end{array}$ & $\begin{array}{l}\text { Permukaan } \\
\text { perabot rumah } \\
\text { tangga, } \\
\text { udara/ruangan, } \\
\text { pakaian }\end{array}$ & $\begin{array}{l}\text { Pemutih (bleach), } \\
\text { alkohol 70\%, karbol, } \\
\text { pembersih lantai, } \\
\text { hidrogen peroksida }\end{array}$ & $\begin{array}{l}\text { Disemprotkan atau } \\
\text { dengan menggunakan } \\
\text { lap (kain microfiber) }\end{array}$ \\
\hline $\begin{array}{lr}\text { Protokol di } & \text { Transportasi } \\
\text { dan Area Publik (Gugus } \\
\text { Tugas } & \text { Percepatan } \\
\text { Penanganan } & \text { COVID-19, } \\
\text { 2020b) } & \\
\end{array}$ & $\begin{array}{l}\text { Transportasi dan } \\
\text { area publik: } \\
\text { terminal, } \\
\text { kendaraan umum }\end{array}$ & $\begin{array}{l}\text { Tidak disebutkan } \\
\text { secara spesifik }\end{array}$ & 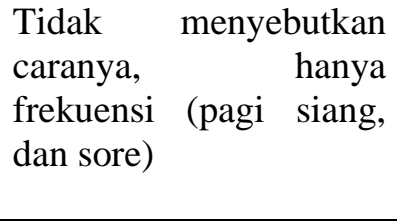 \\
\hline
\end{tabular}

Dilihat dari lokasi/tempat/area disinfeksi, protokol/pedoman tersebut disusun untuk memberi panduan disinfeksi hampir untuk seluruh area publik seperti perkantoran, pusat pebelanjaan, restoran, sekolah, masjid, termasuk perumahan, dan lain-lain. Sasaran disinfeksi adalah benda/permukaan (handle pintu, saklar lampu, komputer, meja, keyboard komputer, dan fasilitas lain yang sering terpegang oleh tangan) dan udara ruangan (tempat kerja) yang terindikasi adanya kontaminan. Untuk jenis disinfektan, direkomendasikan menggunakan larutan pemutih (bleach), alkohol 70\%, karbol/lysol, senyawa diamin, dan hidrogen peroksida dengan frekuensi 2 jam sekali dan paling lambat 12 jam sekali (Kementerian Kesehatan, 2020a; Tim Satgas Covid-19 UGM, 2020). Dalam Protokol Transportasi dan Area Publik, tidak menyebutkan jenis disinfeksi; akan tetapi hanya menyarankan frekuensinya yaitu melakukan disinfeksi sebanyak tiga kali sehari (pagi, siang, dan sore hari) (Gugus Tugas Percepatan Penanganan COVID-19, 2020b).
Dalam hal cara disinfeksi, untuk permukaan benda dilakukan dengan penyemprotan atau dengan menggunakan lap; sedangkan untuk disinfeksi udara dilakukan dengan metode dry mist disinfection (fumigasi/pengasapan dengan menggunakan catridge untuk mengatur uap/asap disinfektan). Seluruh protokol/dokumen menyatakan bahwa dalam melakukan disinfeksi, pelaksana/petugas penyemprot harus menggunakan Alat Pelindung Diri (APD) seperti pakaian khusus, sarung tangan, masker, kacamata goggle, dan sepatu boot; dan membersihkan diri (cuci tangan dangan air yang mengalir setelah melakukan penyemprotan (Gugus Tugas Percepatan Penanganan COVID-19, 2020b). Dari seluruh protokol/panduan disinfeksi tidak ada yang menyebutkan proses dekontaminasi (membersihkan kembali) permukaan/benda yang telah disemprot dengan disinfektan. 


\section{Pelaksanaan disinfeksi saat terjadi wabah Covid-19 di Indonesia}

Sampai dengan akhir Mei 2020, dimana kasus positif Covid-19 mengalami peningkatan cukup pesat, disinfeksi semakin intens dilakukan oleh berbagai pihak dengan maksud memutus rantai penularan. Hasil penelusuran berbagai website kementerian/lembaga maupun media online, diperoleh informasi tentang pelaksanaan disinfeksi di area publik yang berhasil dikumpulkan sebanyak 55 informasi (keterwakilan berbagai wilayah), yang meliputi lokasi, cara, sasaran, jenis disinfektan yang digunakan, penggunaan APD oleh petugas yang melakukan disinfeksi dengan penyemprotan secara langsung. Untuk cara disinfeksi dengan penyemprotan di dalam bilik disinfeksi, dilakukan secara otomatis (elektrik), tidak perlu menggunakan APD lengkap, karena hanya mengamati jalannya alat. Dari 55 sumber tersebut, tidak semuanya memberikan informasi secara lengkap; sebagai contoh untuk jenis disinfektan yang digunakan, informasi yang tersedia sangat terbatas (tidak disebutkan disinfektan apa yang digunakan).

Berdasarkan lokasinya, jenis area publik tersebut meliputi perkantoran (19 informasi), fasilitas kesehatan (8 informasi), pusat perbelanjaan/pasar (7 informasi), perumahan 8 informasi), sekolah umum maupun madrasah (5 informasi), serta jalan raya, terminal dan kendaraan (7 informasi) (Tabel 3 sampai dengan Tabel 8). Berikut adalah rincian hasil pengumpulan data/informasi pelaksanaan disinfeksi di berbagai area publik:

\section{Perkantoran}

Untuk area perkantoran, disinfeksi dilakukan di kantor kementerian/lembaga (tingkat pusat), pemerintah daerah (provinsi, kabupaten/kota) dengan cara penyemprotan secara langsung terhadap permukaan/benda dan penyemprotan di dalam bilik disinfeksi. Sasaran disinfeksi dengan penyemprotan langsung adalah permukaan/benda di seluruh ruangan kerja pegawai, lobby, masjid, kantin dan juga area luar kantor (outdoor). Cukup banyak kantor yang memasang bilik disinfeksi disamping melakukan penyemprotan, seperti yang terjadi dikantor BNN, Ditjen Bimas Kementerian Agama, dan di lingkungan Kantor Pemerintah Kabupaten Garut (Tabel 3) (BNN, 2020; Ditjen Bimas Kristen Kemenag, 2020; Galamedia, 2020). Dalam hal penggunaan disinfektan, dari seluruh informasi pelaksanaan disinfeksi di kantor (19), hanya 3 (tiga) informasi yang menyebutkan jenis disinfektan, yaitu penyemprotan di Kantor Sekretariat Direktorat Jenderal Kekayaan Negara (DJKN), Kementerian Keuangan, menggunakam campuran virkon dan air (DJKN Kemenkeu, 2020); Kantor Pemerintah Kabupaten Bandung menggunakan benzaclin povidone iodine dan aroma jeruk (Pemkab Bandung, 2020), Kantor Pemerintah Kabupaten Karawang, menggunakan larutan pemutih, karbol, dan pembersih lantai(Pemkab Karawang, 2020). Dalam hal penggunaan APD oleh petugas, hampir semua petugas yang melakukan penyemprotan di perkantoran menggunakan APD lengkap (pakaian khusus, sarung tangan, masker, kacamata goggle, dan sepatu boot) (Tabel 3).

Tabel 3. Lokasi/tempat, cara, dan sasaran pelaksanaan disinfeksi selama pandemi Covid-19 di perkantoran di Indonesia, 2020

\begin{tabular}{|c|c|c|c|c|c|}
\hline Lokasi disinfeksi & $\begin{array}{l}\text { Cara } \\
\text { disinfeksi }\end{array}$ & Sasaran disinfeksi & Disinfektan & $\begin{array}{l}\text { APD } \\
\text { petugas }\end{array}$ & $\begin{array}{l}\text { Sumber } \\
\text { informasi }\end{array}$ \\
\hline $\begin{array}{l}\text { Inspektorat } \\
\text { Jenderal } \\
\text { Kemendikbud }\end{array}$ & Penyemprotan & $\begin{array}{l}\text { Permukaan/benda di } \\
\text { ruangan kerja } \\
\text { pegawai dan juga } \\
\text { area luar kantor } \\
\text { (outdoor) }\end{array}$ & $\begin{array}{l}\text { Tidak } \\
\text { disebutkan }\end{array}$ & $\begin{array}{l}\text { APD } \\
\text { lengkap }\end{array}$ & $\begin{array}{l}\text { Itjen } \\
\text { Kemendikbud, } \\
2020\end{array}$ \\
\hline $\begin{array}{l}\text { Lingkungan } \\
\text { Kantor } \quad \text { BPKP } \\
\text { Sulsel }\end{array}$ & Penyemprotan & $\begin{array}{lr}\text { Ruangan } & \text { kantor, } \\
\text { lobby, } & \text { masjid, } \\
\text { kantin, dan area } \\
\text { satpam }\end{array}$ & $\begin{array}{l}\text { Tidak } \\
\text { disebutkan }\end{array}$ & $\begin{array}{l}\text { APD } \\
\text { lengkap }\end{array}$ & $\begin{array}{l}\text { BPKB } \\
2020\end{array}$ \\
\hline
\end{tabular}




\begin{tabular}{|c|c|c|c|c|c|}
\hline Lokasi disinfeksi & $\begin{array}{l}\text { Cara } \\
\text { disinfeksi }\end{array}$ & Sasaran disinfeksi & Disinfektan & $\begin{array}{l}\text { APD } \\
\text { petugas }\end{array}$ & $\begin{array}{l}\text { Sumber } \\
\text { informasi }\end{array}$ \\
\hline $\begin{array}{l}\text { Dinas Pertanian } \\
\text { Kabupaten } \\
\text { Pandeglang }\end{array}$ & Penyemprotan & $\begin{array}{l}\text { Sarpras tempat kerja } \\
\text { dan halaman }\end{array}$ & $\begin{array}{l}\text { Tidak } \\
\text { disebutkan }\end{array}$ & $\begin{array}{l}\text { Tidak } \\
\text { disebutkan }\end{array}$ & $\begin{array}{l}\text { Dinas Pertanian } \\
\text { Kab. } \\
\text { Pandeglang, } \\
2020\end{array}$ \\
\hline $\begin{array}{l}\text { Sekretariat } \\
\text { Direktorat } \\
\text { Jenderal } \\
\text { Kekayaan Negara } \\
\text { (DJKN) }\end{array}$ & Penyemprotan & $\begin{array}{l}\text { Sarpras kantor di } 12 \\
\text { lantai gedung } \\
\text { (basement dan ruang } \\
\text { operator lift). }\end{array}$ & $\begin{array}{l}\text { Campuran } \\
\text { virkon dan } \\
\text { air }\end{array}$ & $\begin{array}{l}\text { APD } \\
\text { lengkap }\end{array}$ & $\begin{array}{l}\text { DJKN } \\
\text { Kemenkeu, } \\
2020\end{array}$ \\
\hline $\begin{array}{ll}\text { Wilayah } & \text { kota } \\
\text { administrasi } & \text { DKI } \\
\text { Jakarta } & \end{array}$ & Penyemprotan & $\begin{array}{ll}\mathrm{Di} \text { dalam } & \text { ruangan } \\
\text { (indoor) } & \text { maupun } \\
\text { luar } & \text { ruangan } \\
\text { (outdoor) } & \text { kantor }\end{array}$ & $\begin{array}{l}\text { Tidak } \\
\text { disebutkan }\end{array}$ & $\begin{array}{l}\text { APD } \\
\text { lengkap }\end{array}$ & $\begin{array}{l}\text { Jakarta Bisnis, } \\
2020\end{array}$ \\
\hline $\begin{array}{l}\text { Kantor Kemenag } \\
\text { Toli-toli Provinsi } \\
\text { Sulawesi Tengah }\end{array}$ & Penyemprotan & semua ruangan & $\begin{array}{l}\text { Tidak } \\
\text { disebutkan }\end{array}$ & $\begin{array}{l}\text { APD } \\
\text { lengkap }\end{array}$ & $\begin{array}{l}\text { Kemenag } \\
\text { Provinsi } \\
\text { Sulawesi } \\
\text { Tengah, } 2020\end{array}$ \\
\hline $\begin{array}{l}\text { Kementerian } \\
\text { Perindustrian, } \\
\text { Jakarta }\end{array}$ & Penyemprotan & Area Gedung & $\begin{array}{l}\text { Tidak } \\
\text { disebutkan }\end{array}$ & $\begin{array}{l}\text { APD } \\
\text { lengkap }\end{array}$ & $\begin{array}{l}\text { Kementerian } \\
\text { Perindustrian, } \\
2020\end{array}$ \\
\hline $\begin{array}{l}\text { Seluruh satuan } \\
\text { kerja kepolisian }\end{array}$ & Penyemprotan & Gedung kantor & $\begin{array}{l}\text { Tidak } \\
\text { disebutkan }\end{array}$ & $\begin{array}{l}\text { Tdk } \\
\text { disebutkan }\end{array}$ & $\begin{array}{l}\text { Tribunnews, } \\
2020\end{array}$ \\
\hline $\begin{array}{l}\text { Kantor } \\
\text { Kementerian } \\
\text { PANRB, Jakarta }\end{array}$ & Penyemprotan & $\begin{array}{lr}\text { Ruang } & \text { kerja } \\
\text { pegawai, } & \text { ruang } \\
\text { pertemuan } & \end{array}$ & $\begin{array}{l}\text { Tidak } \\
\text { disebutkan }\end{array}$ & $\begin{array}{l}\text { APD } \\
\text { lengkap }\end{array}$ & $\begin{array}{l}\text { Kementerian } \\
\text { PANRB, } 2020\end{array}$ \\
\hline $\begin{array}{l}\text { Kantor Pemkab } \\
\text { Bandung, meliputi } \\
\text { area pekantoran } \\
\text { dan masjid }\end{array}$ & Penyemprotan & $\begin{array}{ll}\text { Permukaan benda } \\
\text { dan udara } \\
\text { ruang }\end{array}$ & $\begin{array}{l}\text { Benzaclin } \\
\text { povidone } \\
\text { iodine dan } \\
\text { aroma jeruk }\end{array}$ & $\begin{array}{l}\text { APD } \\
\text { lengkap }\end{array}$ & $\begin{array}{l}\text { Pemkab } \\
\text { Bandung, } 2020\end{array}$ \\
\hline $\begin{array}{l}\text { Kantor Kominfo, } \\
\text { Kota Banjar }\end{array}$ & Penyemprotan & $\begin{array}{l}\text { Permukaan lantai } \\
\text { dan meja, kursi, } \\
\text { pintu, dinding, lantai }\end{array}$ & $\begin{array}{l}\text { Tidak } \\
\text { disebutkan }\end{array}$ & $\begin{array}{l}\text { APD } \\
\text { lengkap }\end{array}$ & $\begin{array}{l}\text { Pemkab Banjar, } \\
2020\end{array}$ \\
\hline $\begin{array}{l}\text { Kantor Pemkab } \\
\text { Karawang. }\end{array}$ & Penyemprotan & $\begin{array}{l}\text { Lantai, dinding, } \\
\text { meja, kursi lemari }\end{array}$ & $\begin{array}{l}\text { Pemutih, } \\
\text { karbol, dan } \\
\text { pembersih } \\
\text { lantai }\end{array}$ & $\begin{array}{l}\text { APD } \\
\text { lengkap }\end{array}$ & $\begin{array}{l}\text { Pemkab } \\
\text { Karawang, } \\
2020\end{array}$ \\
\hline $\begin{array}{l}\text { Kantor } \\
\text { pemerintah kota } \\
\text { (5), Provinsi DKI } \\
\text { Jakarta }\end{array}$ & $\begin{array}{l}\text { Penyemprotan } \\
\text { disinfektan. }\end{array}$ & $\begin{array}{l}\text { di dalam ruangan } \\
\text { (indoor) dan luar } \\
\text { ruangan (outdoor) }\end{array}$ & $\begin{array}{l}\text { Tidak } \\
\text { disebutkan }\end{array}$ & $\begin{array}{l}\text { APD } \\
\text { lengkap }\end{array}$ & $\begin{array}{l}\text { Republika, } \\
2020\end{array}$ \\
\hline $\begin{array}{l}\text { Otoritas Istana } \\
\text { Negara }\end{array}$ & $\begin{array}{l}\text { Bilik } \\
\text { disinfeksi; }\end{array}$ & $\begin{array}{l}\text { Semua pegawai, } \\
\text { pejabat, wartawan, } \\
\text { dan tamu }\end{array}$ & $\begin{array}{l}\text { Tidak } \\
\text { disebutkan }\end{array}$ & $\begin{array}{l}\text { Tidak } \\
\text { berlaku }\end{array}$ & Antara, 2020 \\
\hline $\begin{array}{l}\text { Perkantoran } \\
\text { Pemkab Ponorogo }\end{array}$ & $\begin{array}{l}\text { Bilik } \\
\text { disinfeksi; }\end{array}$ & $\begin{array}{l}\text { Semua pegawai, } \\
\text { pejabat, dan tamu }\end{array}$ & $\begin{array}{l}\text { Tidak } \\
\text { disebutkan }\end{array}$ & - & $\begin{array}{l}\text { Pemkab } \\
\text { Ponorogo, } 2020\end{array}$ \\
\hline $\begin{array}{l}\text { Pusat Litbang } \\
\text { Perumahan dan } \\
\text { Permukiman } \\
\text { Bandung; }\end{array}$ & $\begin{array}{l}\text { Bilik } \\
\text { disinfeksi }\end{array}$ & Para pegawai & $\begin{array}{l}\text { Ozon } \\
\text { Nanomist }\end{array}$ & - & $\begin{array}{l}\text { Litbang } \\
2020\end{array}$ \\
\hline
\end{tabular}




\begin{tabular}{|c|c|c|c|c|c|}
\hline Lokasi disinfeksi & $\begin{array}{l}\text { Cara } \\
\text { disinfeksi }\end{array}$ & Sasaran disinfeksi & Disinfektan & $\begin{array}{l}\text { APD } \\
\text { petugas }\end{array}$ & $\begin{array}{l}\text { Sumber } \\
\text { informasi }\end{array}$ \\
\hline $\begin{array}{l}\text { Kantor } \quad \mathrm{BNN} \text {, } \\
\text { Jakarta }\end{array}$ & $\begin{array}{l}\text { Penyemprotan } \\
\text { dan bilik } \\
\text { disinfeksi } \\
\text { (bides) }\end{array}$ & \begin{tabular}{lr}
\multicolumn{2}{l}{ Penyemprotan: } \\
seluruh & ruangan \\
kantor. & Bides: \\
karyawan & maupun \\
tamu &
\end{tabular} & $\begin{array}{l}\text { Tidak } \\
\text { disebutkan }\end{array}$ & $\begin{array}{l}\text { Tidak } \\
\text { disebutkan }\end{array}$ & BNN, 2020 \\
\hline $\begin{array}{l}\text { Kantor Ditjen } \\
\text { Bimbingan } \\
\text { Masyarakat } \\
\text { Kristen } \\
\text { Kementerian } \\
\text { Agama }\end{array}$ & $\begin{array}{l}\text { Penyemprotan } \\
\text { dan bilik } \\
\text { disinfeksi } \\
\text { (bides) }\end{array}$ & $\begin{array}{l}\text { Penyemprotan: } \\
\text { meja, kenop pintu, } \\
\text { gagang lemari arsip, } \\
\text { skursi, keyboard, } \\
\text { dll. Bides: Pegawai } \\
\text { dan tamu }\end{array}$ & $\begin{array}{l}\text { Tidak } \\
\text { disebutkan }\end{array}$ & $\begin{array}{l}\text { Tidak } \\
\text { disebutkan }\end{array}$ & $\begin{array}{l}\text { Ditjen Bimas } \\
\text { Kristen } \\
\text { Kemenag, } 2020\end{array}$ \\
\hline $\begin{array}{ll}\text { Kantor } & \text { Pemkab } \\
\text { Garut , Provinsi } \\
\text { Jawa Barat }\end{array}$ & $\begin{array}{l}\text { Penyemprotan } \\
\text { dan bilik } \\
\text { desinfeksi } \\
\text { (bides) }\end{array}$ & $\begin{array}{l}\text { Gedung-gedung } \\
\text { fasilitas umum dan } \\
\text { sosial, serta } \\
\text { perkantoran dan } \\
\text { sekolah. }\end{array}$ & $\begin{array}{l}\text { Tidak } \\
\text { disebutkan }\end{array}$ & $\begin{array}{l}\text { Tidak } \\
\text { disebutkan }\end{array}$ & $\begin{array}{l}\text { Galamedia, } \\
2020\end{array}$ \\
\hline
\end{tabular}

Untuk disinfeksi di dalam bilik, informasi penggunaan APD oleh pegawai, maupun pengunjung/tamu tidak dapat diperoleh secara keseluruhan. Gambar 1 menunjukkan salah satu contoh seseorang yang melakukan disinfeksi melalui bilik disinfeksi sebelum memasuki ruangan kantor tanpa memakai APD.
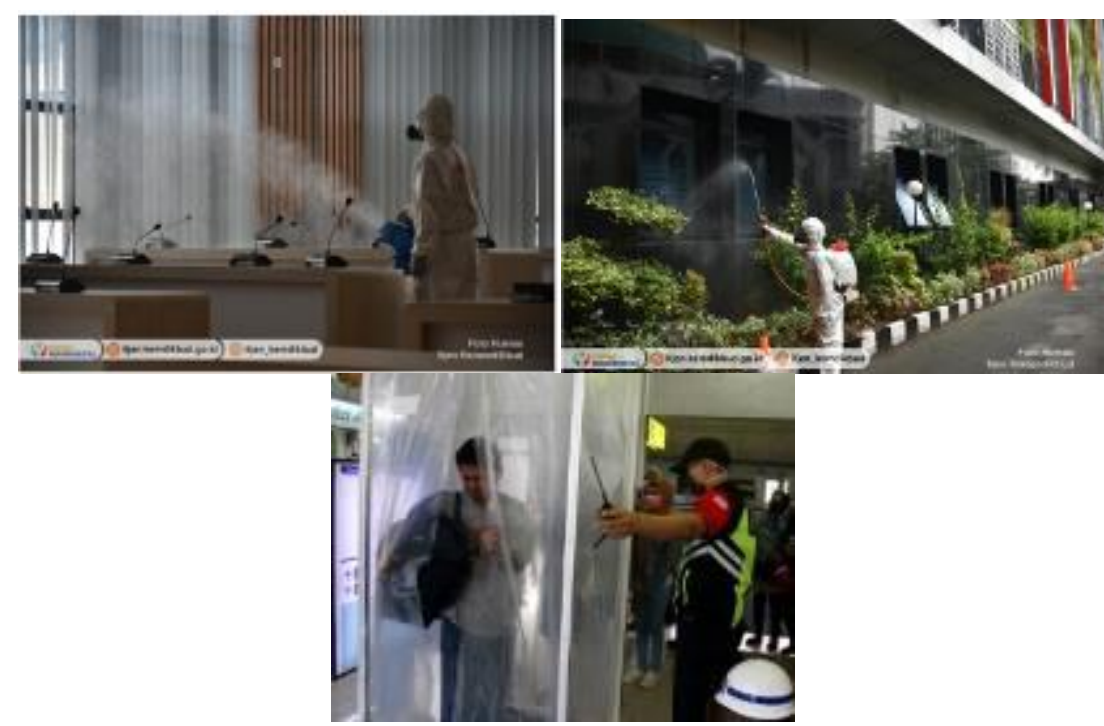

Gambar 1. Disinfeksi di perkantoran dengan penyemprotan langsung (indoor dan outdoor) dan melalui bilik disinfeksi di perkantotan (Antara, 2020; Tempo, 2020)

\section{Fasilitas Kesehatan}

Untuk disinfeksi di fasilitas kesehatan (rumah sakit, puskesmas) dilakukan dengan penyemprotan langsung dan atau pemasangan bilik disinfeksi. Sasaran penyemprotan di rumah sakit/puskesmas ditujukan terutama untuk disinfeksi di permukaan/benda yang berada setiap ruangan, termasuk ruang tunggu pasien, IGD dan tiap poli RS/puskesmas (Tabel 4). Tidak hanya di perkantoran, fasilitas pelayanan kesehatan (RS/puskesmas) di beberapa kabupaten/kota juga memasang bilik disinfeksi. Informasi dari website berbagai media pemberitaan menunjukkan bahwa cukup banyak fasilitas pelayanan kesehatan yang memasang bilik 
disinfeksi, diantaranya adalah pemerintah Kota (Pemkot) Jakarta Pusat berkolaborasi dengan Asosiasi Laundry Indonesia (ASLI) yang menempatkan dua bilik disinfektan di delapan puskesmas (Beritajakarta, 2020). Demikian juga Pemerintah Kabupaten (Pemkab) Lumajang, Jawa Timur, telah menempatkan bilik disinfeksi di sejumlah rumah sakit (RS) dan ruang publik yang ada di wilayah yang strategis (Antara Kalsel, 2020); pemerintah Kota Tangerang menempatkan 50 bilik disinfektan yang tersebar di puskesmas, rumah sakit dan kantor pelayanan publik di Kota Tangerang (Megapolitan Kompas, 2020). Pemasangan bilik disinfeksi dimaksudkan untuk membunuh mikroorganisme/virus dengan menyemprot pakaian yang dikenakan dan barang yang dibawa oleh pengunjung sebelum masuk ke RS/puskesmas.

Dilihat dari jenis disinfektan yang digunakan, informasi hanya diperoleh dari pelaksanaan disinfeksi di puskesmas Jakarta Pusat, yaitu menggunakan benzalkonium chloride untuk penyemprotan di dalam bilik disinfeksi senyawa klorin untuk penyemprotan secara langsung (Beritajakarta, 2020; Pemkot Jakarta Pusat, 2020). Disinfeksi di 5 fasyankes lainnya, tidak menyebutkan jenis disinfektannya (Tabel 4). Dalam melakukan penyemprotan, petugas menggunakan APD lengkap, seperti pelindung kepala, pelindung mata (goggle), sarung tangan, pakaian khusus, pelindung kaki (sepatu boot) (Tabel 4) (Pemkab Sinjai, 2020; Pemkot Jakarta Pusat, 2020).

Tabel 4. Lokasi/tempat, cara, dan sasaran pelaksanaan disinfeksi selama pandemi Covid-19 di fasilitas kesehatan (RS dan puskesmas) di Indonesia, 2020

\begin{tabular}{|c|c|c|c|c|c|}
\hline Lokasi disinfeksi & $\begin{array}{l}\text { Cara } \\
\text { disinfeksi }\end{array}$ & Sasaran disinfeksi & Disinfektan & $\begin{array}{l}\text { APD } \\
\text { petugas }\end{array}$ & $\begin{array}{l}\text { Sumber } \\
\text { informasi }\end{array}$ \\
\hline $\begin{array}{l}\text { Rumah sakit }(\mathrm{RS}) \\
\text { Lumajang, Jawa Timur }\end{array}$ & $\begin{array}{l}\text { Bilik } \\
\text { disinfeksi }\end{array}$ & $\begin{array}{l}\text { Seluruh } \\
\text { pengunjung RS }\end{array}$ & $\begin{array}{l}\text { Tidak } \\
\text { disebutkan }\end{array}$ & - & $\begin{array}{l}\text { Antara Kalsel, } \\
2020\end{array}$ \\
\hline $\begin{array}{l}\text { Puskesmas di Kota } \\
\text { (Pemkot) Jakarta Pusat }\end{array}$ & $\begin{array}{l}\text { Bilik } \\
\text { disiinfeksi }\end{array}$ & $\begin{array}{l}\text { Seluruh } \\
\text { pengunjung } \\
\text { puskesmas }\end{array}$ & $\begin{array}{l}\text { Benzalkonium } \\
\text { chloride (aman } \\
\text { bagi tubuh) }\end{array}$ & - & $\begin{array}{l}\text { Beritajakarta, } \\
2020\end{array}$ \\
\hline $\begin{array}{l}\text { Puskesmas } \\
\text { Kabupaten Garut }\end{array}$ & $\begin{array}{l}\text { Bilik } \\
\text { disinfeksi }\end{array}$ & $\begin{array}{l}\text { Seluruh } \\
\text { pengunjung } \\
\text { puskesmas }\end{array}$ & $\begin{array}{l}\text { Tidak } \\
\text { disebutkani }\end{array}$ & - & $\begin{array}{l}\text { Galamedia, } \\
2020\end{array}$ \\
\hline $\begin{array}{l}\text { Puskesmas, rumah sakit } \\
\text { dan kantor pelayanan } \\
\text { publik Kota Tangerang }\end{array}$ & $\begin{array}{l}\text { Bilik } \\
\text { disinfeksi }\end{array}$ & $\begin{array}{l}\text { Pengunjung } \\
\text { puskesmas, RS, } \\
\text { area publik }\end{array}$ & $\begin{array}{l}\text { Tidak } \\
\text { disebutkan }\end{array}$ & - & $\begin{array}{l}\text { Megapolitan } \\
\text { Kompas, } 2020\end{array}$ \\
\hline $\begin{array}{lr}\text { Rumah Sakit Darurat } \\
\text { Wisma } & \text { Atlet } \\
\text { Kemayoran } & \end{array}$ & $\begin{array}{l}\text { Bilik } \\
\text { disinfeksi }\end{array}$ & Pengunjung RSD & $\begin{array}{l}\text { Tidak } \\
\text { disebutkan }\end{array}$ & - & $\begin{array}{l}\text { Wartaekonomi, } \\
2020\end{array}$ \\
\hline $\begin{array}{lr}\text { Puskesmas } & \text { di } \\
\text { Kabupaten } & \text { Berau, } \\
\text { Provinsi } & \text { Kalimantan } \\
\text { Timur } & \end{array}$ & Penyemprotan & $\begin{array}{l}\text { Seluruh } \\
\text { puskesmas }\end{array}$ & $\begin{array}{l}\text { Tidak } \\
\text { disebutkan }\end{array}$ & $\begin{array}{l}\text { Tidak } \\
\text { disebutkan }\end{array}$ & $\begin{array}{l}\text { Ibukotakita, } \\
2020\end{array}$ \\
\hline $\begin{array}{l}\text { Beberapa puskesmas di } \\
\text { Kota Administratif } \\
\text { Jakarta Pusat }\end{array}$ & Penyemprotan & $\begin{array}{l}\text { Seluruh area } \\
\text { puskesmas }\end{array}$ & $\begin{array}{l}\text { Senyawa } \\
\text { mengandung } \\
\text { klorin }\end{array}$ & $\begin{array}{l}\text { APD } \\
\text { lengkap }\end{array}$ & $\begin{array}{l}\text { Pemkot Jakarta } \\
\text { Pusat, } 2020\end{array}$ \\
\hline $\begin{array}{l}\text { RS dan puskesmas di } \\
\text { Kabupaten Sinjai }\end{array}$ & Penyemprotan & $\begin{array}{l}\text { Ruangan pasien, } \\
\text { IGD dan tiap poli } \\
\text { RS, } \\
\text { puskesmas }\end{array}$ & $\begin{array}{l}\text { Tidak } \\
\text { disebutkan }\end{array}$ & $\begin{array}{l}\text { APD } \\
\text { lengkap }\end{array}$ & $\begin{array}{l}\text { Pemkab Sinjai, } \\
2020\end{array}$ \\
\hline
\end{tabular}




\section{Pusat perbelanjaan/mall/pasar}

Pelaksanaan disinfeksi di pusat perbelanjaan/mall dilakukan dengan penyemprotan disinfektan permukaan/benda didalam ruangan (lobby, toilet, area tenant, lift) dan luar ruangan (pagar, kaca, pintu masuk, dinding, kaca etalase, gerai ATM). Disinfeksi di pasar dilakukan dengan memasang bilik disinfeksi di pintu masuk (gerbang) pasar dengan sasaran pelanggan, pedagang, dan pengunjung pasar (Tabel 5).
Dari seluruh informasi pelaksanaan disinfeksi di pusat perbelanjaan/mall/pasar, hanya disinfeksi di Pasar Badung, Kota Denpasar yang menyebutkan jenis diinfektan yang digunakan yaitu larutan hipoklorit $0,1 \%$ yang disemprotkan di dalam bilik disinfeksi (Media Indonesia, 2020). Dalam hal penggunaan APD, masih terdapat penyemprot di pasar yang menggunakan APD tetapi tidak lengkap (bahkan hanya menggunakan masker) (Gambar 2).

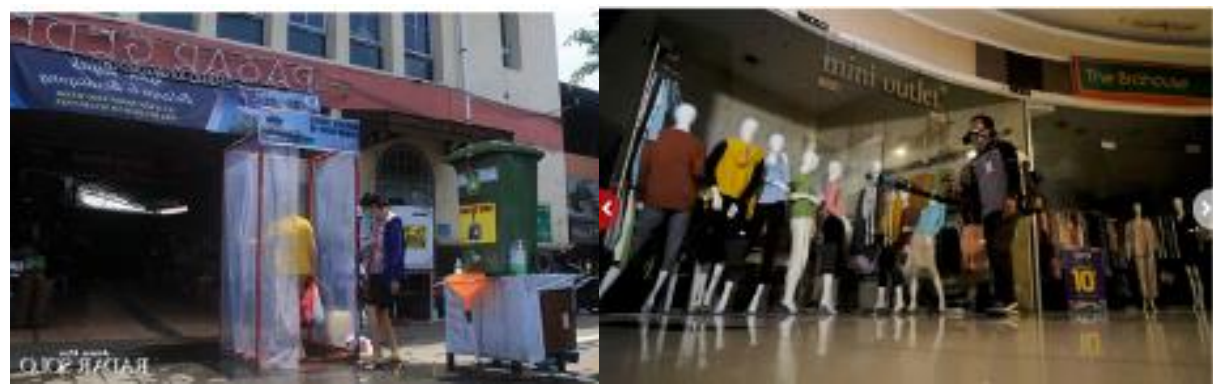

Gambar 2. Contoh bilik disinfeksi di pasar dan penyemprotan di mall (Beritasatu, 2020; Radar Solo, 2020)

Tabel 5. Lokasi/tempat, cara, dan sasaran pelaksanaan disinfeksi selama pandemi Covid-19 di pusat perbelanjaan/mall/pasar di Indonesia, 2020

\begin{tabular}{|c|c|c|c|c|c|}
\hline Lokasi disinfeksi & $\begin{array}{l}\text { Cara } \\
\text { disinfeksi }\end{array}$ & $\begin{array}{l}\text { Sasaran } \\
\text { disinfeksi }\end{array}$ & Disinfektan & $\begin{array}{l}\text { APD } \\
\text { petugas }\end{array}$ & $\begin{array}{l}\text { Sumber } \\
\text { informasi }\end{array}$ \\
\hline $\begin{array}{l}\text { Pasar Badung di Kota } \\
\text { Denpasar, Bali }\end{array}$ & $\begin{array}{l}\text { Bilik } \\
\text { disinfeksi }\end{array}$ & $\begin{array}{l}\text { Pelanggan, } \\
\text { pedagang, dan } \\
\text { pengunjung }\end{array}$ & $\begin{array}{l}\text { Larutan } \\
\text { hipoklorit } \\
0,1 \%\end{array}$ & - & $\begin{array}{l}\text { Media } \\
\text { Indonesia, } 2020\end{array}$ \\
\hline Pasar Gede Solo & $\begin{array}{l}\text { Bilik } \\
\text { disinfeksi }\end{array}$ & $\begin{array}{l}\text { Seluruh pedagang } \\
\text { maupun pembeli }\end{array}$ & $\begin{array}{l}\text { Tidak } \\
\text { disebutkan }\end{array}$ & - & $\begin{array}{l}\text { Radar Solo, } \\
2020\end{array}$ \\
\hline $\begin{array}{l}\text { Pusat perbelanjaan } \\
\text { Mall Tangerang City, } \\
\text { Tangerang }\end{array}$ & Penyemprotan & $\begin{array}{l}\text { Dinding, lantai, } \\
\text { gerai ATM, kaca } \\
\text { etalase }\end{array}$ & $\begin{array}{l}\text { Tidak } \\
\text { disebutkan }\end{array}$ & $\begin{array}{l}\text { APD tidak } \\
\text { lengkap }\end{array}$ & $\begin{array}{l}\text { Beritasatu, } \\
2020\end{array}$ \\
\hline Pasar Bacan Makasar & Penyemprotan & $\begin{array}{l}\text { Seluruh area } \\
\text { pasar }\end{array}$ & $\begin{array}{l}\text { Tidak } \\
\text { disebutkan }\end{array}$ & $\begin{array}{l}\text { APD } \\
\text { lengkap }\end{array}$ & $\begin{array}{l}\text { Detiknews, } \\
2020 \mathrm{c}\end{array}$ \\
\hline $\begin{array}{l}\text { Lippo Mall Kemang, } \\
\text { Jakarta }\end{array}$ & Penyemprotan & $\begin{array}{l}\text { Benda dalam mall } \\
\text { (lobby, toilet, area } \\
\text { tenant, tempat } \\
\text { makan, lift) }\end{array}$ & $\begin{array}{l}\text { Tidak } \\
\text { disebutkan }\end{array}$ & $\begin{array}{l}\text { APD } \\
\text { lengkap }\end{array}$ & Liputan6, 2020 \\
\hline $\begin{array}{l}\text { Pusatperbelanjaan/mall } \\
\text { (Bencoolen } \\
\text { Mall) Indah } \\
\text { sekitarnya. }\end{array}$ & Penyemprotan & $\begin{array}{l}\text { Permukaan/benda } \\
\text { di dalam dan luar } \\
\text { ruangan mall }\end{array}$ & $\begin{array}{l}\text { Tidak } \\
\text { disebutkan }\end{array}$ & $\begin{array}{l}\text { Tidak } \\
\text { disebutkan. }\end{array}$ & $\begin{array}{l}\text { Pemprov } \\
\text { Bengkulu, } 2020\end{array}$ \\
\hline $\begin{array}{l}\text { Pasar Cihapit, Kota } \\
\text { Bandung }\end{array}$ & $\begin{array}{l}\text { Bilik } \\
\text { disinfeksi }\end{array}$ & Pengunjung pasar & $\begin{array}{l}\text { Tidak } \\
\text { disebutkan }\end{array}$ & $\begin{array}{l}\text { Tidak } \\
\text { disebutkan }\end{array}$ & $\begin{array}{l}\text { Republika, } \\
2020\end{array}$ \\
\hline
\end{tabular}




\section{Perumahan}

Penyemprotan di perumahan tidak hanya dilakukan terhadap pagar dan pintu rumah di luar rumah, tetapi terhadap peralatan yang berada di dalam rumah yang sering dijamah seperti handle pintu/jendela, meja, kursi, lemari, dan lain-lain. Fasilitas lain yang berada di perumahan seperti tempat ibadah, tempat usaha warga, kantor sekretariat RW, penanganan prasarana dan saran umum (PPSU) juga tidak luput dari penyemprotan. Disamping penyemprotan, di beberapa akses masuk ke perumahan dipasang bilik disinfektan untuk mendesinfeksi penghuni perumahan maupun tamu yang akan berkunjung (Radarjember,
2020). Bahkan salah satu perumahan di Bekasi memasang bilik disinfeksi berukuran besar untuk menyemprot kendaraan yang akan masuk ke dalam komplek perumahan (Merdeka.com, 2020). Beberapa contoh penyemprotan di perumahan dapat dilihat dalam Gambar 3. Hampir seluruh informasi pelaksanaan disinfeksi di perumahan tidak menyebutkan jenis disinfektan yang digunakan (Tabel 6). Masih terdapat petugas penyemprot yang memakai APD tidak lengkap (hanya menggunakan masker dan topi) saat melakukan penyemprotan (Detiknews, 2020d; Pemkot Administratif Jakarta Barat, 2020), bahkan hanya masker (Detiknews, 2020b).

Tabel 6. Lokasi/tempat, cara, dan sasaran pelaksanaan disinfeksi selama pandemi Covid-19 di perumahan di Indonesia, 2020

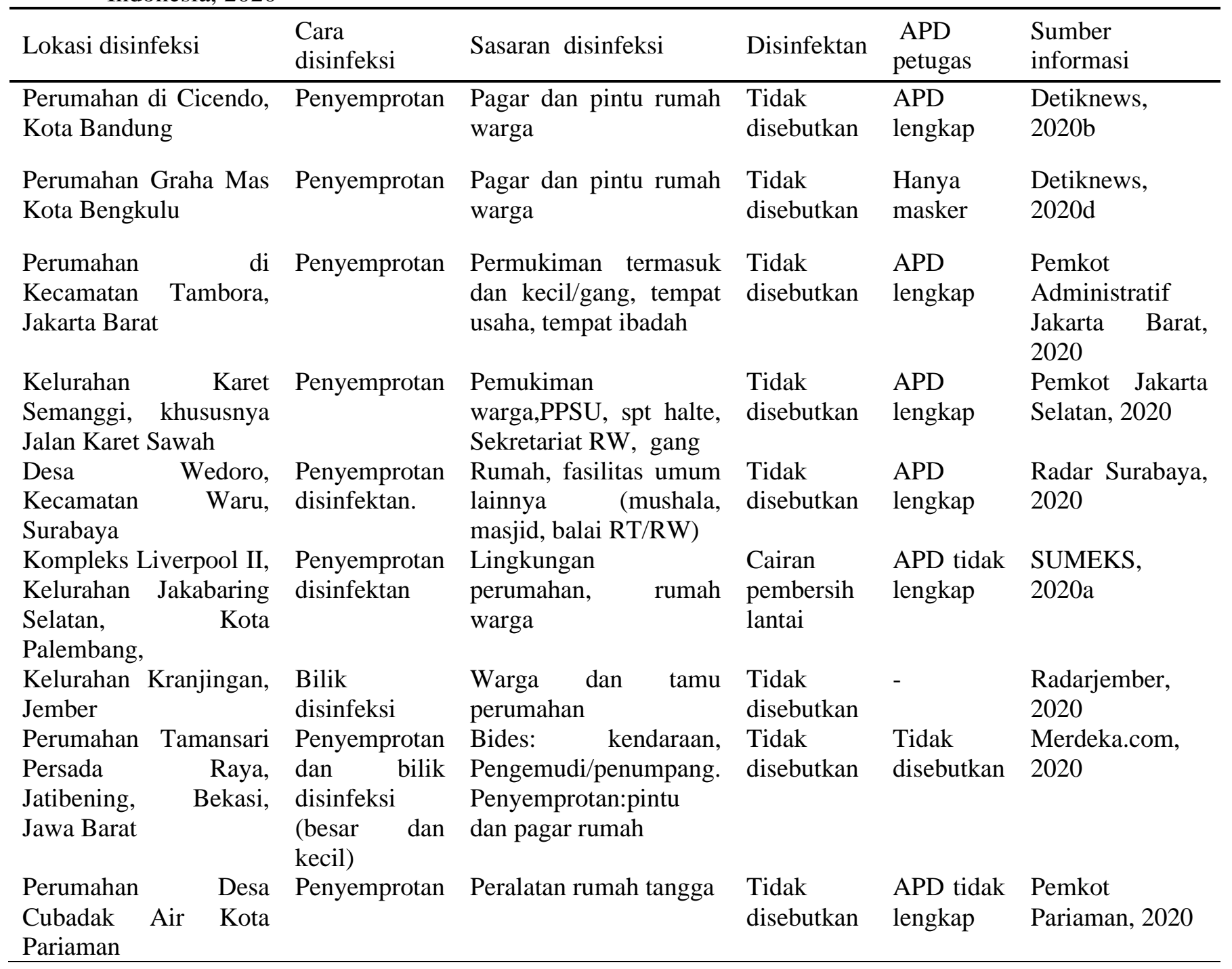



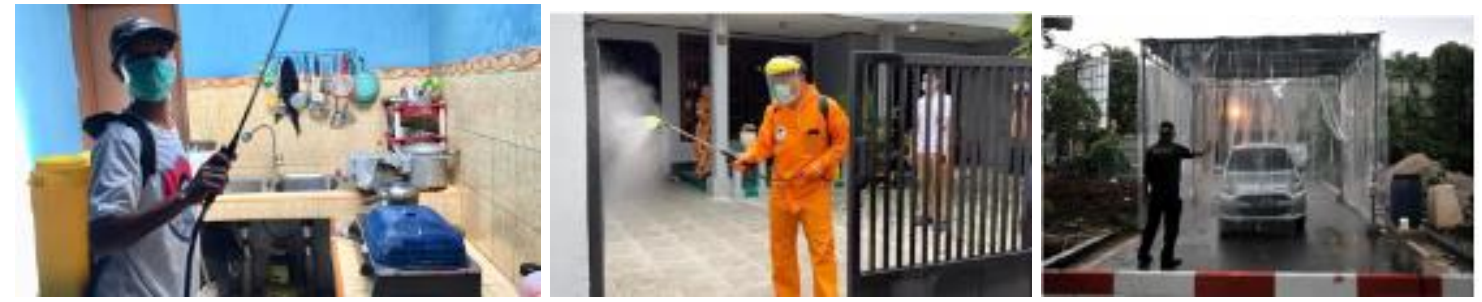

Gambar 3. Penyempotan di perumahan indoor dan outdoor, serta penyemprotan mobil di dalam bilik disinfeksi (Merdeka.com, 2020; Pemkot Pariaman, 2020; Radar Surabaya, 2020)

\section{Sekolah}

Di area sekolah, disinfeksi dilakukan di semua tingkatan; mulai dari PAUD, TK, SD, SMP sampai SMA atau sederajat (Tabel 7). Disinfeksi dilakukan dengan penyemprotan disinfektan, dengan sasaran permukaan/benda yang sering disentuh (meja, kursi, papan tulis, pintu masuk kelas, ruang guru, dan ruang lainnya), lantai, dan dinding. Hanya satu sumber informasi yang menyebutkan jenis disinfektan yang digunakan, yaitu disinfeksi yang dilakukan di SDN 3 Bandar Agung, Lampung Timur; yaitu menggunakan pemutih pakaian. Demikian juga informasi penggunaan APD oleh petugas yang melakukan penyemprotan, informasi tidak diperolah secara lengkap; tetapi dari salah satu kegiatan, diketahui bahwa terdapat petugas penyemprot yang menggunakan APD tidak lengkap (hanya memakai baju seragam biasa, masker dan sarung tangan) (Pemkab Lampung Timur, 2020)

Tabel 7. Lokasi/tempat, cara, dan sasaran pelaksanaan disinfeksi selama pandemi Covid-19 di sekolah di Indonesia, 2020

\begin{tabular}{|c|c|c|c|c|c|c|}
\hline Lokasi disinfeksi & $\begin{array}{c}\text { Cara } \\
\text { disinfeksi }\end{array}$ & \multicolumn{2}{|c|}{$\begin{array}{c}\text { Sasaran } \\
\text { disinfeksi }\end{array}$} & Disinfektan & $\begin{array}{l}\text { APD } \\
\text { petugas }\end{array}$ & $\begin{array}{c}\text { Sumber } \\
\text { informasi }\end{array}$ \\
\hline $\begin{array}{l}\text { TK At Taqwa dan } \\
\text { Masjid Al Hasanah, , } \\
\text { Komplek Madit Hubad } \\
\text { TNI AD, Cijantung, } \\
\text { Jakarta Timur }\end{array}$ & Penyemprotan & $\begin{array}{l}\text { Lantai, } \\
\text { permukaa } \\
\text { yang } \\
\text { disentuh }\end{array}$ & $\begin{array}{r}\text { a/benda } \\
\text { sering }\end{array}$ & $\begin{array}{l}\text { Tidak } \\
\text { disebutkan }\end{array}$ & $\begin{array}{l}\text { APD } \\
\text { lengkap }\end{array}$ & BNPB, 2020 \\
\hline $\begin{array}{l}\text { SMA, SMK, dan SMP } \\
\text { di Kota Bandung }\end{array}$ & Penyemprotan & $\begin{array}{l}\text { Ruang } \\
\text { kantor, } \\
\text { halaman }\end{array}$ & $\begin{array}{r}\text { kelas, } \\
\text { dan }\end{array}$ & $\begin{array}{l}\text { Tidak } \\
\text { disebutkan }\end{array}$ & $\begin{array}{l}\text { APD } \\
\text { lengkap }\end{array}$ & $\begin{array}{l}\text { Disdik } \\
\text { Provinsi Jawa } \\
\text { Barat, 2020 }\end{array}$ \\
\hline $\begin{array}{l}\text { SDN } 3 \text { Bandar Agung, } \\
\text { Lampung Timur }\end{array}$ & Penyemprotan & $\begin{array}{l}\text { Seluruh } \\
\text { ruangan } \\
\text { ruang } \\
\text { halaman) }\end{array}$ & $\begin{array}{r}\text { area } \\
\text { (kelas, } \\
\text { kantor, }\end{array}$ & $\begin{array}{l}\text { Pemutih } \\
\text { pakaian }\end{array}$ & $\begin{array}{l}\text { Tidak ada } \\
\text { informasi }\end{array}$ & $\begin{array}{l}\text { Pemkab } \\
\text { Lampung } \\
\text { Timur, } 2020\end{array}$ \\
\hline $\begin{array}{l}\text { Gedung sekolah di Kota } \\
\text { Sibolga, mulai dari } \\
\text { PAUD } \\
\text { SLTA/sederajat }\end{array}$ & Penyemprotan & $\begin{array}{l}\text { Meja, } \\
\text { papan } \\
\text { sampai } \\
\text { kantin }\end{array}$ & $\begin{array}{r}\text { kursi, } \\
\text { tulis, } \\
\text { area }\end{array}$ & $\begin{array}{l}\text { Tidak } \\
\text { disebutkan }\end{array}$ & $\begin{array}{l}\text { Tidak ada } \\
\text { informasi }\end{array}$ & $\begin{array}{l}\text { Pemkot } \\
\text { Sibolga, } 2020\end{array}$ \\
\hline $\begin{array}{lr}\text { Seluruh } & \text { lokasi } \\
\text { Madrasah Aliyah } & \text { Negeri 1 Belitung } \\
\end{array}$ & Penyemprotan & $\begin{array}{l}\text { Seluruh } \\
\text { kelas }\end{array}$ & uang & $\begin{array}{l}\text { Tdk } \\
\text { disebutkan }\end{array}$ & $\begin{array}{l}\text { APD } \\
\text { lengkap }\end{array}$ & $\begin{array}{l}\text { Kemenag } \\
\text { Bangka } \\
\text { Belitung, 2020 } \\
\end{array}$ \\
\hline
\end{tabular}

Area transportasi (jalan raya, terminal, kendaraan)

Informasi tentang pelaksanaan disinfeksi di area transportasi meliputi penyemprotan yang dilakukan di jalan raya dan terminal, dengan sasaran seluruh permukaan/benda yang ditemui di kedua lokasi tersebut seperti berbagai kendaraan, 
halte, sarana dan prasarana jalan dan terminal, bahkan masyarakat yang berada di sekitarnya. Salah satu kecamatan di Kabupaten Lampung Tengah secara spesifik melakukan disinfeksi terhadap kendaraan yang sedang melalui wilayah tersebut (Pemkab Lampung Tengah, 2020).

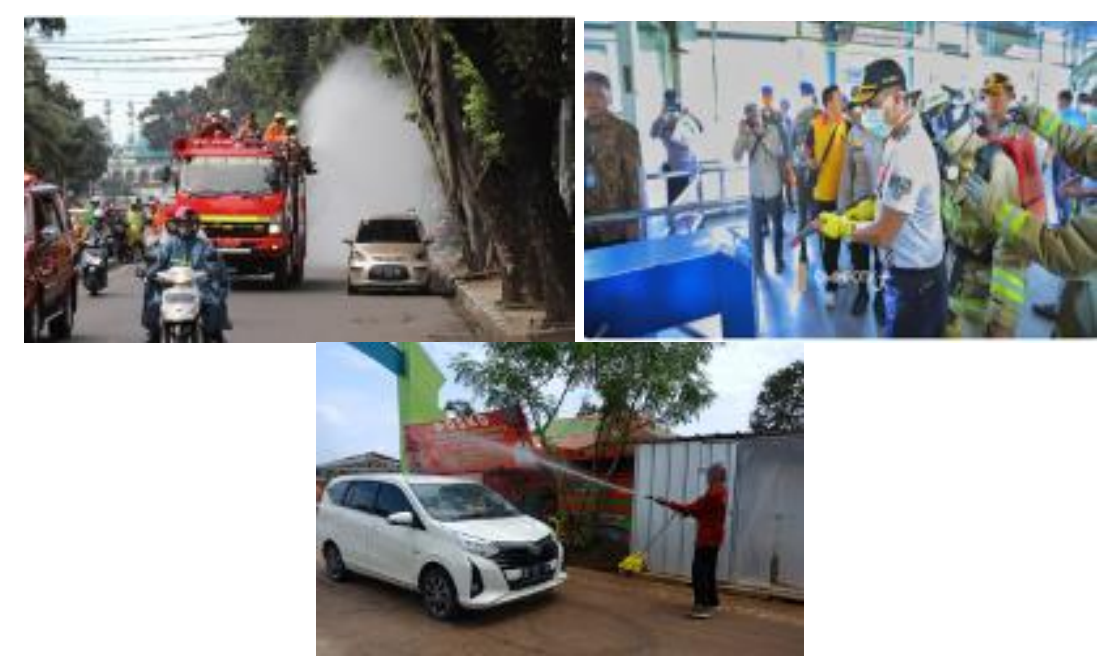

Gambar 4. Penyemprotan di jalan raya, terminal, dan kendaraan di berbagai kabupaten/kota di Indonesia (Detiknews, 2020a; Pemkab Lampung Tengah, 2020; Pemkot Administratif Jakarta Timur, 2020)

Dalam hal jenis disinfektan yang digunakan dalam penyemprotan, dari seluruh informasi yang dapat dikumpulkan, tidak satupun yang menyebutkannya. Untuk penggunaan APD, diperoleh informasi bahwa saat penyemprotan petugas tidak seluruh informasi menyatakan bahwa penyemprot memakai APD lengkap (Tabel 8). Masih terdapat petugas yang memakai APD tidak lengkap, seperti tanpa pelindung mata (goggle) dan pelindung kepala/helm (Pemkot Administratif Jakarta Timur, 2020).

Tabel 8. Lokasi/tempat, cara, dan sasaran pelaksanaan disinfeksi selama pandemi Covid-19 di jalan raya dan terminal di Indonesia, 2020

\begin{tabular}{|c|c|c|c|c|c|}
\hline Lokasi disinfeksi & $\begin{array}{l}\text { Cara } \\
\text { disinfeksi }\end{array}$ & $\begin{array}{l}\text { Sasaran } \\
\text { disinfeksi }\end{array}$ & Disinfektan & $\begin{array}{l}\text { APD } \\
\text { Petugas }\end{array}$ & $\begin{array}{l}\text { Sumber } \\
\text { informasi }\end{array}$ \\
\hline $\begin{array}{lr}\text { Jalan protokol } & (46 \\
\text { lokasi)dan } & \text { jalan } \\
\text { perkampungan } & \text { di } \\
\text { Jakarta. } & \end{array}$ & Penyemprotan & $\begin{array}{l}\text { Jalan dan } \\
\text { sekitarnya (halte, } \\
\text { kendaraan) }\end{array}$ & $\begin{array}{l}\text { Tidak } \\
\text { disebutkan }\end{array}$ & $\begin{array}{l}\text { APD } \\
\text { lengkap }\end{array}$ & $\begin{array}{l}\text { Detiknews, } \\
\text { 2020a }\end{array}$ \\
\hline $\begin{array}{l}\text { Jalan-jalan protokol dan } \\
\text { area zona merah di } \\
\text { Kota Semarang }\end{array}$ & Penyemprotan & $\begin{array}{lr}\text { Jalan dan } \\
\text { sekitarnya (halte, } \\
\text { kendaraan) }\end{array}$ & $\begin{array}{l}\text { Tidak } \\
\text { disebutkan }\end{array}$ & $\begin{array}{l}\text { APD } \\
\text { lengkap }\end{array}$ & $\begin{array}{l}\text { Kompas TV, } \\
2020\end{array}$ \\
\hline $\begin{array}{l}\text { Kampung Srisawahan } \\
\text { Kecamatan Punggur, } \\
\text { Lampung Tengah }\end{array}$ & Penyemprotan & $\begin{array}{l}\text { Kendaraan yang } \\
\text { lewat }\end{array}$ & $\begin{array}{l}\text { Tidak } \\
\text { disebutkan }\end{array}$ & $\begin{array}{l}\text { Tidak ada } \\
\text { informasi }\end{array}$ & $\begin{array}{l}\text { Pemkab } \\
\text { Lampung } \\
\text { Tengah, } 2020\end{array}$ \\
\hline $\begin{array}{l}\text { Terminal Kampung } \\
\text { Rambutan, Kecamatan } \\
\text { Ciracas, Jakarta Timur }\end{array}$ & Penyemprotan & $\begin{array}{l}\text { Shelter dan kabin } \\
\text { Trans Jakarta, } \\
\text { fasilitas terminal } \\
\text { Kampung }\end{array}$ & $\begin{array}{l}\text { Tidak } \\
\text { disebutkan }\end{array}$ & $\begin{array}{l}\text { APD tidak } \\
\text { lengkap }\end{array}$ & $\begin{array}{l}\text { Pemkot } \\
\text { Administratif } \\
\text { Jakarta Timur, } \\
2020\end{array}$ \\
\hline $\begin{array}{l}\text { Jalan di Kabupaten } \\
\text { Tuban, Jawa Timur }\end{array}$ & Penyemprotan & Jalan di 17 desa & $\begin{array}{l}\text { Tidak } \\
\text { disebutkan }\end{array}$ & $\begin{array}{l}\text { APD } \\
\text { lengkap }\end{array}$ & $\begin{array}{l}\text { Pertamina, } \\
2020\end{array}$ \\
\hline
\end{tabular}




\begin{tabular}{|c|c|c|c|c|c|}
\hline Lokasi disinfeksi & $\begin{array}{l}\text { Cara } \\
\text { disinfeksi }\end{array}$ & $\begin{array}{l}\text { Sasaran } \\
\text { disinfeksi }\end{array}$ & Disinfektan & $\begin{array}{l}\text { APD } \\
\text { Petugas }\end{array}$ & $\begin{array}{l}\text { Sumber } \\
\text { informasi }\end{array}$ \\
\hline Wilayah Jabodetabek. & Penyemprotan & $\begin{array}{l}\text { Jalan protokol } \\
\text { Jabodetabek, } \\
\text { gang dan fasilitas } \\
\text { publik }\end{array}$ & $\begin{array}{l}\text { Tidak } \\
\text { disebutkan }\end{array}$ & $\begin{array}{l}\text { APD } \\
\text { lengkap }\end{array}$ & Tempo, 2020 \\
\hline $\begin{array}{l}\text { Jalan protokol di } \\
\text { Mojokerto, Jawa Timur }\end{array}$ & Penyemprotan & $\begin{array}{ll}\text { Jalan } & \text { dan } \\
\text { fasilitasnya } & \end{array}$ & $\begin{array}{l}\text { Tidak } \\
\text { disebutkan }\end{array}$ & $\begin{array}{l}\text { Tidak } \\
\text { disebutkan }\end{array}$ & Yuwono, 2020 \\
\hline
\end{tabular}

\section{Pengaruh disinfektan terhadap kesehatan}

Sesuai dengan tujuan disinfeksi yaitu mendekontaminasi bakteri atau virus dari permukaan/benda, maka disinfektan yang digunakan biasanya merupakan bahan kimia yang bersifat destruktif. Pada dasarnya,seluruh disinfektan berbahan aktif kimia bersifat toksik, yang dapat menimbulkan risiko baik terhadap lingkungan maupun terhadap kesehatan manusia apabila tidak digunakan sesuai instruksi. Bukti-bukti pengaruh pajanan disinfektan terhadap kesehatan, dari hasil penelitian di berbagai negara masih terbatas pada dampak terhadap pekerja (industri dan fasilitas kesehatan) (Izu, Yamamoto and Asahi, 2000; Sastre et al., 2011; Casey et al., 2017; Chiu et al., 2017; Dumas et al., 2017, 2019).

Dari hasil penelusuran berbagai website, jenis disinfektan dalam pelaksanaan disinfeksi di berbagai area publik tidak banyak terungkap. Hanya beberapa yang menyebutkan jenis disinfektan saat melakukan penyemprotan (langsung maupun dengan bilik disinfeksi), yaitu penyemprotan di salah satu sekolah di Bandar Lampung (Pemkab Lampung Timur, 2020), perumahan di Kota Palembang (SUMEKS, 2020a, 2020b), Pasar di Kota Denpasar (Media Indonesia, 2020), fasyankes di Jakarta Pusat (Pemkot Jakarta Pusat, 2020), Kantor Pemda Kabupaten Bandung yang menyebutkannya (Pemkab Bandung, 2020); itupun tidak menyebut jenisnya secara spesifik. Dari berbagai lokasi/tempat tersebut diketahui bahwa disinfektan yang digunakan yaitu pemutih pakaian, cairan pembersih lantai (karbol), larutan hipoklorit $0,1 \%$, senyawa tidak mengandung klorin, benzaclin povidone iodine dan aroma jeruk. (Media Indonesia, 2020; Pemkab Lampung Timur, 2020; Pemkot Jakarta Pusat, 2020; SUMEKS, 2020a, 2020b). Berikut adalah karakteristik/sifat kimia dan pengaruh pajanan dari berbagai bahan tersebut:

Pemutih pakaian merupakan senyawa sodium hipoklorit dikenal sebagai asmagen, yaitu agen pencetus asma (Association of Occupational and Environmental Clinics, 2012). Pajanan dalam kadar rendah akan mengakibatkan iritasi, sakit tenggorokan dan batuk, sedangkan dalam kadar tinggi bisa mengakibatkan dyspnea atau sesak nafas akibat tidak terpenuhinya pasokan oksigen ke paru-paru, gangguan otot bronkus sehingga keluar masuk udara terganggu, dan edema paru (Sastre et al., 2011). Jika mengenai kulit dan mata, dapat menyebabkan iritasi (World Health Organization, 2004). Sampai saat ini belum ditemukan penawar klorin, sehingga untuk menghindari efek pajanan klorin adalah dengan mematuhi aturan penggunaannya.

Karbol merupakan cairan pembersih lantai merupakan senyawa fenolik yang memiliki bau tar-pinus yang khas. Pada kadar $5 \%$ digunakan sebagai bakterisida, fungisida dan virucidal untuk enveloped virus. Masuknya fenol ke dalam tubuh dapat menyebabkan iritasi pada saluran pencernaan. Pengaruh pajanan terhadap kulit, mulai dari eritema hingga korosi dan nekrosis. Pengaruh sistemik utama, termasuk disritmia jantung, gangguan pernapasan, asidosis metabolik, gagal ginjal, urin gelap, methaemoglobinaemia, efek neurologis, syok kardiovaskular, koma, dan kematian (World Health Organization, 1994; Occupational Safety and Health Branch. Labour Department, 2007)

Benzaclin povidone iodine adalah obat luar yang berfungsi sebagai antiseptik dan disinfeksi spektrum luas yang lebih banyak digunakan untuk membersihkan serta membunuh bakteri, jamur, dan virus pada kulit. Dalam dosis besar untuk luka yang luas 
bisa mengakibatkan gangguan pada ginjal, tingginya sodium pada darah dan asidosis metabolik. Tidak dianjurkan untuk ibu hamil dengan usia kandungan di bawah 32 minggu, atau pasien yang menjalani pengobatan dengan lithium, memakai iodin povidon terlalu sering (Occupational Safety and Health Branch. Labour Department, 2007).

Virkon adalah desinfektan yang mengandung okson, natrium dodecyl benzene sulfonate, asam sulfamat, dan buffer anorganik; efektif melawan patogen virus, bakteri, dan jamur yang penting untuk pengendalian infeksi, termasuk HIV, hepatitis B dan C, MRSA, VRE, dan Salmonella (US Environmental Protection Agency, 2018). Pajanan terhadap tubuh, berpotensi menimbulkan pengaruh terhadap kulit (iritasi), mata (risiko kerusakan serius), iritasi saluran pernapasan (Compas, 2014; LanXess, 2019).

Benzalconium chloride, merupakan obat yang biasa digunakan untuk menghambat pertumbuhan mikroorganisme seperti jamur dan virus pada luka kulit dan mencegah infeksi luka pada kulit. Kerusakan pada lensa mata dan permukaan kornea konjungtival, konjungtivitis (pengobatan jangka panjang dengan obat tetes mata yang mengandung benzalconium chloride sebagai pengawet), kelumpuhan otot, dan radang kulit yang sangat parah (Merchel Piovesan Pereira and Tagkopoulos, 2019)

Ozon nanomist merupakan disinfektan berbahan dasar oksigen yang diubah menjadi ozon. Ozon itu kemudian dilarutkan dalam air, dan diuapkan. Ini secara teknis dapat dimanfaatkan sebagai pengganti disinfektan kimiawi terutama yang digunakan pada bilik, dengan potensi risiko yang lebih rendah selama mengikuti durasi dan ketentuan yang berlaku (Lembaga Ilmu Pengetahuan Indonesia, 2020). Walaupun demikian, penggunaannya harus sesuai ketentuan, karena pajanan ozon yang berlebihan dapat menimbulkan gangguan terhadap kesehatan; seperti iritasi mata, mulut kering, batuk, hidung tersumbat, mengi, sesak napas, dan nyeri dada pada orang yang bahkan dalam keadaan sehat (World Health Organization, 2004).

\section{PEMBAHASAN}

Terjadinya wabah Covid-19 membuat semua pihak berupaya melakukan pencegahan penularan virus corona yang merupakan penyebab penyakit tersebut dengan melakukan disinfeksi. Disinfeksi merupakan proses dekontaminasi yang menghilangkan atau membunuh segala hal terkait mikroorganisme (baik virus dan bakteri) pada objek permukaan benda mati.

Dilihat dari lokasi/tempatnya, hampir seluruh area publik mulai dari perkantoran kementerian sampai balai desa/RT/RW, rumah sakit/puskesmas, sekolah, perumahan, terminal, bahkan jalan raya tidak luput dari disinfeksi. Hal ini dilakukan hampir di seluruh wilayah Indonesia yang terjangkit Covid-19. Pelaksanaan disinfeksi area publik dilakukan dengan penyemprotan tempat di mana biasanya terdapat kerumunan orang, seperti pusat perbelanjaan/mall atau pasar, terminal, halte, rumah sakit, puskesmas, dan lainlain.Besar kemungkinan masyarakat yang berada di lokasi penyemprotan akan terpajan oleh bahan (disinfektan) yang disemprotkan. Risiko untuk terpajan cukup tinggi, terutama pada awal ditetapkannya pandemi Covid-19, masyarakat belum diwajibkan menggunakan masker. Selama pandemi Covid-19 ini,belum terlaporkan adanya kasus gangguan kesehatan akibat penyemprotan disinfeksi; bukan berarti penyemprotan disinfektan tidak berpengaruh terhadap kesehatan. Hal ini karena pengaruh pajanan terhadap bahan kimia dari proses disinfeksi tersebut kemungkinan bersifat kronis (efek muncul dalam waktu yang lama).

Selain dengan penyemprotan secara langsung, penyemprotan dilakukan di dalam bilik disinfeksi; yaitu penyemprotan terhadap pakaian yang dikenakan dan barang yang dibawa oleh seseorang dengan maksud disinfeksi permukaan/benda tersebut. Walaupun tujuannya adalah melakukan disinfeksi terhadap pakaian atau barang yang dibawa oleh seseorang, tetapi disinfektan yang disemprotkan di dalam bilik sangat besar kemungkinannya untuk terhirup dan mengenai kulit, mulut dan mata. Jika hal ini terjadi, akan berisiko terhadap kesehatan, mengingat sebagian besar disinfektan yang digunakan, seperti larutan pemutih pakaian dan pembersih lantai bersifat iritatif. 
Sebetulnya Badan Kesehatan Dunia maupun Kementerian Kesehatan tidak merekomendasi penggunaan bilik disinfeksi. Kementerian Kesehatan telah mengeluarkan surat Edaran no HK.02.02/III/375/2020 tentang Penggunaan Bilik Disinfeksi Dalam Rangka Pencegahan Penularan Covid-19, yang merekomendasikan untuk tidak menggunakan bilik disinfeksi di tempat dan fasulitas umum (TFU) serta pemukiman (Kementerian Kesehatan, 2020c). Walaupun demikian, sampai saat ini bilik disinfeksi masih cukup banyak digunakan. Masih banyaknya masyarakat yang masih menggunakan bilik disinfeksi, kemungkinan disebabkan oleh karena masyarakat belum paham akan bahaya kesehatan akibat pajanan disinfektan, atau edaran tersebut belum tersosialisasi dengan baik.

Dilihat dari jenisnya, penggunaan disinfektan dalam kegiatan penyemprotan (langsung maupun dengan bilik disinfeksi) telah sesuai dengan disinfektan yang disarankan protokol/pedoman pencegahan penularan Covid-19, kecuali benzaclin povidone iodine. Salah satu kabupaten melakukan disinfeksi dengan menyemprotkan bahan tersebut, karena dianggap senyawa paling aman. Secara fungsi, benzaclin povidone iodine lebih tepat digunakan sebagai antiseptik. Dalam daftar yang dikeluarkan oleh badan perlindungan lingkungan Amerika Serikat (EPA) maupun protokol/pedoman pencegahan penularan Covid-19 (Kementerian Kesehatan, 2020a; Tim Satgas Covid-19 UGM, 2020; US Environmental Protection Agency, 2020), tidak menyebutkan benzaclin povidone iodine; artinya senyawa tersebut bukan disinfektan yang disarankan untuk disinfeksi dalam pencegahan penularan Covid-19. Jika digunakan untuk disinfeksi permukaan/benda, kemungkinan kurang efektif dan hanya akan mencemari permukaan/benda dan menimbulkan dampak terhadap lingkungan dan kesehatan jika digunakan secara masif dan terus menerus. Dengan terbatasnya informasi tentang jenis disinfektan yang digunakan dari hasil penelusuran yang diperoleh, masih dimungkinkan digunakannya jenis disinfektan yang lain, sehingga risiko kesehatan yang timbul kemungkinan lebih beragam.
Dalam hal penggunaan APD oleh petugas penyemprot, dari hasil penelusuran dapat diketahui bahwa masih terdapat petugas yang menggunakan APD tidak lengkap, bahkan hanya menggunakan masker. Dalam hal ini, petugas penyemprot berisiko sangat tinggi untuk terpajan disinfektan secara terus menerus dan dalam dosis yang lebih tinggi dibandingkan dengan masyarakat umum. Hal ini karena terkait pekerjaannya yang harus melakukan kegiatan penyemprotan di berbagai tempat dengan frekuensi sampai dengan 3 kali (sesuai dengan Protokol Transportasi dan Area Publik (Gugus Tugas Percepatan Penanganan COVID-19, 2020b).

Jika dibandingkan dengan protokol yang telah dikeluarkan oleh pemerintah (Gugus Tugas Percepatan Penanggulangan Covid-19), terdapat ketidak sesuaian dalam pelaksanaannya; diantaranya adalah dalam hal cara disinfeksi. Masih terdapat disinfeksi di dalam bilik disinfeksi walaupun pemerintah telah mengeluarkan edaran untuk tidak menggunakannya karena dapat membahayakan kesehatan. Selain itu dalam disinfeksi di area transportasi, petugas melakukan penyemprotan terhadap kendaraan, sementara Protokol Transportasi dan Area Publik tidak menganjurkan hal tersebut. Untuk jenis disinfektan yang digunakan dalam disinfeksi langsung maupun melalui bilik disinfeksi, menggunakan disinfektan yang tidak sesuai dengan anjuran dalam protokol, seperti benzaclin povidone iodine yang cenderung berfungsi sebagai antiseptik. Penggunaan ozon nanomist, walaupun tidak dianjurkan dalam protokol, tetapi dianggap lebih aman. Akan tetapi dalam implementasinya harus sesuai dengan ketentuan karena pajanan ozon yang berlebihan dapat berpengaruh terhadap kesehatan. Dalam hal penggunaan APD oleh petugas penyemprot, beberapa informasi menyebutkan bahwa petugas tidak menggunakan APD secara lengkap pada saat melakukan penyemprotan (bahkan terdapat petugas yang hanya menggunakan masker). Beberapa ketidaksesuaian tersebut akan berakibat pada timbulnya risiko kesehatan masyarakat. 


\section{KESIMPULAN DAN SARAN}

\section{Kesimpulan}

Pelaksanaan disinfeksi dalam upaya pencegahan dan penularan Covid-19 saat terjadi pandemi cukup intens baik dilakukan oleh institusi pemerintah, swasta maupun masyarakat. Pelaksanaan disinfeksi di area publik masih terdapat yang tidak sesuai dengan ketentuan/anjuran dalam protokol percepatan penanggulangan Covid-19 (khususnya pencegahan penularannya). Berdasarkan dari cara (penyemprotan), sasaran disinfeksi (benda yang sering disentuh), dan disinfektan yang digunakan (bersifat iritatif); berpotensi menumbulkan risiko kesehatan. Di beberapa area publik (perkantoran, pusat perbelanjaan, bahkan di perumahan) masih melakukan disinfeksi di dalam bilik disinfeksi, walaupun pemerintah telah mengeluarkan edaran berupa rekomendasi untuk tidak menggunakan bilik disinfeksi, karena sangat berisiko terhadap kesehatan.

\section{Saran}

Perlu sosialisasi dan edukasi terhadap masyarakat tentang protokol pencegahan penularan Covid-19 dan risiko kesehatan dari disinfeksi terutama dengan penyemprotan dalam bilik disinfeksi.

\section{KONTRIBUTOR PENULIS}

Kontributor penulis dalam artikel ini adalah ATH sebagai kontributor utama yang memiliki tugas sebagai penulis artikel dan analisis data, sedangkan EL dan TP sebagai kontributor anggota yang bertugas melakukan pengumpulan data dan informasi serta analisis data.

\section{UCAPAN TERIMAKASIH}

Kami mengucapkan terima kasih kepada Sri Irianti, SKM, M.Phil, Ph.D yang telah memberi bimbingan dalam penulisan artikel ini.

\section{DAFTAR PUSTAKA}

Antara (2020) Istana Negara Pasang Bilik Disinfektan untuk Sterilisasi Tamu - Nasional Tempo.co, Tempo. Available at: https://nasional.tempo.co/read/1320128/istan a-negara-pasang-bilik-disinfektan-untuksterilisasi-tamu/full\&view=ok (Accessed: 22 April 2020).

Antara Kalsel (2020) Pemkab Lumajang tempatkan bilik disinfeksi di RS dan ruang publik. Available at:

https://kalsel.antaranews.com/nasional/berita/ 1385434/pemkab-lumajang-tempatkan-bilikdisinfeksi-di-rs-dan-ruangpublik?utm_source=antaranews\&utm_mediu $\mathrm{m}=$ nasional\&utm _ campaign=antaranews (Accessed: 27 March 2020).

Association of Occupational and Environmental Clinics (2012) AOEC Exposure Code Lookup. Available at: http://www.aoecdata.org/ExpCodeLookup.as px (Accessed: 8 April 2020)

Beritajakarta (2020) Dua Bilik Disinfektan Ditempatkan di Delapan Puskesmas Jakpus. Available at: http://www.beritajakarta.id/read/78351/duabilik-disinfektan-ditempatkan-di-delapanpuskesmas-jakpus\#.XtlqDPkzY2w (Accessed: 1 April 2020).

Beritasatu (2020) Penyemprotan Disinfektan di Pusat Perbelanjaan. Available at https://www.beritasatu.com/galerifoto/33015-penyemprotan-disinfektan-dipusat-perbelanjaan.html. (Accessed: 17 March 2020).

BNN (2020) Lakukan Langkah Antisipatif, BNN Sediakan Bilik Disinfektan. Available at https://bnn.go.id/lakukan-langkah-antisipatifbnn-sediakan-bilik-disinfektan/ (Accessed: 26 March 2020).

BNPB (2020) Penyemprotan Disinfektan Pencegahan Wabah Covid-19 di Komplek Madit Hubad TNI AD. Available at: https://siaga.bnpb.go.id/hkb/berita/penyempr otan-disinfectant-pencegahan-wabah-covid19-di-komplek-madit-hubad-tni-ad (Accessed: 17 March 2020).

BPKB Sulsel (2020) BPKP Sulsel Lakukan Disinfeksi di Lingkungan Kantor.

Casey, M. L. et al. (2017) 'Health problems and disinfectant product exposure among staff at a large multispecialty hospital', Am J Infect Control, 45(10), pp. 1133-1138. doi: 10.1016/j.ajic.2017.04.003.

Chiu, S. et al. (2017) 'Respiratory and Ocular Symptoms Among Employees of an Indoor Waterpark Resort - Ohio, 2016', MMWR. Morbidity and Mortality Weekly Report, 66, pp. 986989. doi: 10.15585/mmwr.mm6637a5.

Compas (2014) Material Safety Data Sheet: Virkon. Available at: https://www.gov.mb.ca/sd/eal/registries/5433 bipole/jul252016updates/sds_sheet_virkon.pd f. (Accessed: 22 June 2020).

Detiknews (2020a) Cegah Corona, Sejumlah Jalan Protokol Jakarta Disemprot Disinfektan Hari Ini. Available

:

\section{,}


https://news.detik.com/berita/d-

5035140/cegah-corona-sejumlah-jalanprotokol-jakarta-disemprot-disinfektan-hariini (Accessed: 31 May 2020).

Detiknews (2020b) Posgab Jabar Lakukan Penyemprotan Disinfektan di Rumah Warga. Available at: https://news.detik.com/fotonews/d-4980657/posgab-jabar-lakukanpenyemprotan-disinfektan-di-rumah-warga (Accessed: 17 April 2020).

Detiknews (2020c) Sterilasi Penyemprotan Disinfektan di Pasar Bacan Pacinan Makassar Cegah COVID-19.

Available

https://news.detik.com/berita/d-

5023089/sterilasi-penyemprotan-disinfektandi-pasar-bacan-pacinan-makassar-cegahcovid-19 (Accessed: 21 May 2020).

Detiknews (2020d) Warga di Bengkulu Inisiatif Semprot Disinfektan ke Rumah-rumah. Available at: https://news.detik.com/berita/d-

4965813/warga-di-bengkulu-inisiatifsemprot-disinfektan-ke-rumah-rumah (Accessed: 5 April 2020).

Dinas Pertanian Kab. Pandeglang (2020) Cegah Covid19, Kantor Dinas Pertanian Kabupaten Pandeglang Disemprot Disinfektan.

Disdik Provinsi Jawa Barat (2020) Penyemprotan Disinfektan di SMAN 2 Bandung. Available at: http://disdik.jabarprov.go.id/news/2076/peny emprotan-disinfektan-di-sman-2-bandung (Accessed: 30 March 2020).

Ditjen Bimas Kristen Kemenag (2020) Cegah Penyebaran Virus Corona, Ditjen Bimas Kristen Lakukan Penyemprotan Disinfektan. Available https://bimaskristen.kemenag.go.id/news122-cegah-penyebaran-virus-corona-ditjenbimas-kristen-lakukan-penyemprotandisinfektan.html (Accessed: 14 April 2020).

DJKN Kemenkeu (2020) Cegah COVID-19, DJKN Semprot Cairan Disinfektan ke Seluruh Ruangan Kantor. Available at: https://www.djkn.kemenkeu.go.id/berita/baca /20250/Cegah-COVID-19-DJKN-SemprotCairan-Disinfektan-ke-Seluruh-RuanganKantor.html (Accessed: 19 March 2020).

Dumas, O. et al. (2017) 'Occupational exposure to disinfectants and asthma control in US nurses', European Respiratory Journal, 50(4), pp. 1-10. doi: 10.1183/13993003.002372017.

Dumas, O. et al. (2019) 'Association of Occupational Exposure to Disinfectants With Incidence of Chronic Obstructive Pulmonary Disease Among US Female Nurses', JAMA Netw Open, 2(e1913563).

Galamedia (2020) Cegah Covid-19, Pemkab Garut Perbanyak Pemasangan Bilik Disinfektan. Available at: https://www.galamedianews.com/?arsip $=252$ $157 \&$ judul=cegah-covid- 19 -pemkab-garutperbanyak-pemasangan-bilik-disinfektan (Accessed: 27 March 2020).

Gugus Tugas Percepatan Penanganan COVID-19 (2020a) Daftar Protokol. Available at: https://www.covid19.go.id/daftar-protokol/ (Accessed: 3 April 2020).
Gugus Tugas Percepatan Penanganan COVID-19 (2020b) Protokol Penanganan COVID-19 di Area dan Transportasi Publik. Available at: https://covid19.go.id/p/protokol/protokolpenanganan-covid-19-di-area-dantransportasi-publik (Accessed: 31 March 2020).

Gugus Tugas Percepatan Penanganan COVID-19 (2020c) Situasi COVID-19 di Indonesia. Available https://www.covid19.go.id/situasi-viruscorona/ (Accessed: 3 April 2020).

Ibukotakita (2020) PMI Berau Lakukan Penyemprotan Disinfektan di Puskesmas. Available at: https://ibukotakita.com/pmi-berau-lakukanpenyemprotan-disinfektan-di-puskesmas (Accessed: 1 April 2020).

Itjen Kemendikbud (2020) Penyemprotan cairan disinfektan di area kantor Itjen. Available at: https://itjen.kemdikbud.go.id/public/post/deta il/penyemprotan-cairan-disinfektan-di-areakantor-itjen (Accessed: 21 March 2020).

Izu, K., Yamamoto, O. and Asahi, M. (2000) 'Occupational skin injury by hydrogen peroxide', Dermatology, 201, pp. 61-4.

Jakarta Bisnis (2020) Pemprov DKI Lakukan Penyemprotan Disinfektan, Ini Daftar Titik Lokasinya. Available at: https://jakarta.bisnis.com/read/20200321/77/1 216427/pemprov-dki-lakukan-penyemprotandesinfektan-ini-daftar-titik-lokasinya (Accessed: 21 March 2020).

Kantor Staf Presiden RI (2020) Daftar Protokol Area Publik dan Transportasi. Available at: http://ksp.go.id/wpcontent/uploads/2020/03/Protokol-Area-danTransportasi-Publik-COVID-19.pdf (Accessed: 3 April 2020).

Kemenag Bangka Belitung (2020) Cegah Corona, Seluruh Madrasah Aliyah Negeri 1 Belitung Dilakukan Penyemprotan. Available at: https://babel.kemenag.go.id/id/ berita/503629/Cegah-Corona-MansabelLakukan-Penyemprotan-Seluruh-LokasiMadrasah (Accessed: 2 April 2020)

Kemenag Provinsi Sulawesi Tengah (2020) Cegah Covid-19, Kemenag Tolitoli Lakukan Penyemprotan Disinfektan. Available at: https://sulteng.kemenag.go.id/berita/detail/ce gah-covid19-kemenag-tolitoli-lakukanpenyemprotan-disinfektan (Accessed: 2 April 2020).

Kementerian Kesehatan (2020a) Panduan Kegiatan Menjaga Kebersihan Lingkungan dan Langkah-langkah Disinfeksi Dalam Rangka Pencegahan Penularan Covid 19. Edited by Direktorat Kesehatan Lingkungan. Jakarta: Kementerian Kesehatan RI.

Kementerian Kesehatan (2020b) Panduan Pencegahan Penularan Covid-19 di Tempat dan Fasilitas Umum. Indonesia. Available at: https://covid19.go.id/p/protokol/panduanpencegahan-penularan-covid-19-di-tempatdan-fasilitas-umum (Accessed: 20 April 2020).

Kementerian Kesehatan (2020c) 'Surat Edaran Nomor HK.02.02/III/375/2020 Tentang Penggunaan 
Bilik Disinfeksi dalam Rangka Pencegahan Penularan COVID-19'. Jakarta, p. 3. Available at: http://www.pusatkrisis.kemkes.go.id/suratedaran-tentang-penggunaan-bilik-disinfeksidalam-rangka-pencegahan-penularan-c.

Kementerian PANRB (2020) Putus Penyebaran Covid19, Seluruh Ruangan Kementerian PANRB Disemprot Disinfektan. Available at: https://www.menpan.go.id/site/beritaterkini/putus-penyebaran-covid-19-seluruhruangan-kementerian-panrb-disemprotdisinfektan (Accessed: 21 March 2020).

Kementerian Perindustrian (2020) Kegiatan Penyemprotan Cairan Disinfektan di Kemenperin. Available at: https://kemenperin.go.id/artikel/21625/Kegiat an-Penyemprotan-Cairan-Disinfektan-diKemenperin (Accessed: 15 March 2020).

Kompas TV (2020) Cegah Covid-19 dengan Penyemprotan Disinfektan Serentak. Available at: https://www.kompas.tv/article/74063/cegahcovid-19-dengan-penyemprotan-disinfektanserentak (Accessed: 1 April 2020).

LanXess (2019) SAFETY DATA SHEET: Virkon. Available at: https://syndel.com/wpcontent/uploads/2019/01/Virkon-S-SDS.pdf (Accessed: 22 June 2020).

Lembaga Ilmu Pengetahuan Indonesia (2020) Ozon Nanomist untuk Solusi Disinfektan Nonkimia. Available http://lipi.go.id/siaranpress/Ozon-Nanomistuntuk-Solusi-Disinfektan-Nonkimia/21984 (Accessed: 22 June 2020).

Liputan6 (2020) Cegah Covid-19, Petugas Semprot Mall dengan Disinfektan. Available at: https://www.liputan6.com/onoff/read/4209482/foto-cegah-covid-19petugas-semprot-mall-dengandisinfektan?page=1 (Accessed: 23 March 2020).

Litbang PU (2020) Puskim Pasang Bilik Disinfektan Ozon Nanomist Sebagai Bentuk Pencegahan COVID-19.

Media Indonesia (2020) Pasar Badung kini Dilengkapi Bilik Disinfektan. Available at: https://mediaindonesia.com/read/detail/29959 8-pasar-badung-kini-dilengkapi-bilikdisinfektan (Accessed: 28 March 2020).

Megapolitan Kompas (2020) Pemkot Tangerang Tempatkan 50 Bilik Disinfektan di Puskesmas dan Rumah Sakit. Available at: https://megapolitan.kompas.com/read /2020/03/26/13353351/pemkot-tangerangtempatkan-50-bilik-disinfektan-dipuskesmas-dan-rumah (Accessed: 26 March 2020).

Merchel Piovesan Pereira, B. and Tagkopoulos, I. (2019) 'Benzalkonium Chlorides: Uses, Regulatory Status, and Microbial Resistance.', Applied and environmental microbiology, 85(13). doi: 10.1128/AEM.00377-19.

Merdeka.com (2020) Antisipasi Corona, Perumahan di Bekasi Pasang Bilik Disinfektan. Available at: https://www.merdeka.com/foto/peristiwa/116 2073/20200331190047-antisipasi-corona- perumahan-di-bekasi-pasang-bilik-

disinfektan-001-nfi.html (Accessed: 31 March 2020).

Occupational Safety and Health Branch. Labour Department (2007) Chemical Safety in the Workplace. Guidance Notes on Safe Use of Chemical safety Disifectans. First. Hongkong: Labour Department. Available at: https://www.labour.gov.hk/eng/public/os/C/D isinfectants.pdf.

Pemkab Bandung (2020) Pemkab Bandung Lakukan Disinfeksi di Lingkungan Perkantoran. Available at: http://www.bandungkab.go.id/arsip/pemkabbandung-lakukan-disinfeksi-di-lingkunganperkantoran (Accessed: 24 March 2020).

Pemkab Banjar (2020) Gedung Pemberitaan Kominfo Banjar Di Lakukan Penyemprotan Disinfektan. Available at: https://banjarkab.go.id/gedung-pemberitaankominfo-banjar-di-lakukan-penyemprotandisinfektan/ (Accessed: 9 April 2020).

Pemkab Karawang (2020) Disinfektan Mulai Dilakukan, Warga diminta Disinfeksi Mandiri. Available at:

https://www.karawangkab.go.id/headline/disi nfektan-mulai-dilakukan-warga-dimintadisinfeksi-mandiri (Accessed: 18 March 2020).

Pemkab Lampung Tengah (2020) Penyemprotan Disinfektan pada Kendaraan yang Melintas, Srisawahan, Punggur. Available at: http://web.lampungtengahkab.go.id/beritapenyemprotan-disinfektan-pada-kendaraanyang-melintas-srisawahan-punggur.html (Accessed: 14 May 2020).

Pemkab Lampung Timur (2020) Antisipasi Corona, SDN 3 Bandar Agung Semprot Disinfektan Lingkungan Sekolah. Available at: http://lampungtimurkab.go.id/read/1442/ antisipasi-corona-sd-n-3-bandar-agungsemprot-disinfektan-lingkungan-sekolah (Accessed: 24 March 2020).

Pemkab Ponorogo (2020) Dinkes Ponorogo Pasang Bilik Disinfektan Di Kantor Pemkab. Available https://ponorogo.go.id/2020/04/03/dinkesponorogo-pasang-bilik-disinfektan-di-kantorpemkab/ (Accessed: 3 April 2020).

Pemkab Sinjai (2020) Dinkes Sinjai Semprot Disinfektan 4 Puskesmas. Available at https://www.sinjaikab.go.id/v4/2020/03/25/sinjai-semprot-disinfektan-4-puskesmas/ (Accessed: 25 March 2020).

Pemkot Administratif Jakarta Barat (2020) Disinfeksi Massal di Tujuh RW Tambora. Available at: http://barat.jakarta.go.id/?p=berita\&id=4273 (Accessed: 11 May 2020).

Pemkot Administratif Jakarta Timur (2020) Fasilitas Umum di Terminal Kampung Rambutan Disemprot Disinfektan. Available at: https://timur.jakarta.go.id/v15/news/Pemerint ahan/5667/ Fasilitas-Umum-di-TerminalKampung-Rambutan-Disemprot-Disinfektan (Accessed: 24 March 2020).

Pemkot Jakarta Pusat (2020) Bantu Bilik Disinfektan, Pemkot Jakpus Kolaborasi dengan Asosiasi 
Laundry Available at: https://pusat.jakarta.go.id/?berita=Bantu.Bilik .Disinfektan,.Pemkot.

Jakpus.Kolaborasi.dengan.Asosiasi.Laundry $\&$ mod=fullmain\&section=info\&action=news \&id=0000006190 (Accessed: 31 March 2020).

Pemkot Jakarta Selatan (2020) PPSU Kelurahan Karet Semanggi Disinfeksi Lingkungan Cegah Penyebaran COVID-19. Available at: https://selatan.jakarta.go.id/news/2020/03/pps u-kelurahan-karet-semanggi-disinfeksilingkungan-cegah-penyebaran-covid-19 (Accessed: 27 March 2020).

Pemkot Pariaman (2020) Inisiatif Karang Taruna Cubadak Air, Lakukan Penyemprotan Disinfektan ke Rumah-Rumah Warga. Available https://pariamankota.go.id/berita/inisiatifkarang-taruna-cubadak-air-lakukanpenyemprotan-disinfektan-ke-rumah-rumahwarga (Accessed: 27 March 2020).

Pemkot Sibolga (2020) Seluruh Sekolah Disemprot Disinfektan, Wali Kota Pimpin Langsung Penyemprotan. Available at https://sibolgakota.go.id/home/seluruhsekolah-disemprot-disinfektan-wali-kotapimpin-langsung-penyemprotan/ (Accessed: 1 April 2020)

Pemprov Bengkulu (2020) Lawan Covid-19, Satpol PP Provinsi Semprotkan Disenfektan di Mall. Available https://bengkuluprov.go.id/lawan-covid-19satpol-pp-provinsi-semprotkan-disenfektandimall/?utm_source=rss\&utm_medium=rss\&ut m_campaign=lawan-covid-19-satpol-ppprovinsi-semprotkan-disenfektan-di-mall (Accessed: 27 March 2020).

Pemprov DKI Jakarta (2020) 'Panduan Disinfeksi'. Jakarta: Pemprov DKI Jakarta.

Pertamina (2020) Pertamina Semprot Disinfektan Jalan di 17 Desa Kabupaten Tuban. Available at: https://www.pertamina.com/id/newsroom/csr-news/pertamina-semprotdisinfektan-jalan-di-17-desa-kabupatentuban- (Accessed: 17 April 2020).

Radar Solo (2020) Pasar Gede Sediakan Bilik Disinfektan. Available at: https://radarsolo.jawapos.com/read/2020/03/3 0/186284/pasar-gede-sediakan-bilikdisinfektan (Accessed: 30 March 2020).

Radar Surabaya (2020) BHS Lakukan Penyemprotan Disinfektan di 790 Rumah dan Fasilitas Umum. Available https://radarsurabaya.jawapos.com/read/2020 /03/28/185866/bhs-lakukan-penyemprotandisinfektan-di-790-rumah-dan-fasilitas-umum (Accessed: 28 March 2020).

Radarjember (2020) Cegah Penularan Covid-19: Semprot Disinfektan Sebelum Masuk Perumahan. Available at: https://radarjember.jawapos.com/beritadaerah/jember/02/04/2020/ semprotdisinfektan-sebelum-masuk-perumahan/ (Accessed: 2 April 2020).
Republika (2020) In Picture: Bilik Disinfeksi Swadaya di Pasar Cihapit Bandung. Available at: https://republika.co.id/berita/q8b55m314/bili k-disinfeksi-swadaya-di-pasar-cihapitbandung (Accessed: 5 April 2020).

Sastre, J. et al. (2011) 'Airway response to chlorine inhalation (bleach) among cleaning workers with and without bronchial hyperresponsiveness', American Journal of Industrial Medicine. John Wiley \& Sons, Ltd, 54(4), pp. 293-299. doi: 10.1002/ajim.20912.

SUMEKS (2020a) Cegah Virus Corona, Warga Racik Disinfektan. Available at: https://sumeks.co/cegah-virus-corona-wargaracik-disinfektan/ (Accessed: 25 March 2020).

SUMEKS (2020b) Warga-Puskesmas Lakukan Penyemprotan Disinfektan. Available at: https://sumeks.co/warga-puskesmas-lakukanpenyemprotan-disinfektan/ (Accessed: 29 March 2020).

Tempo (2020) COVID-19, PMI Lakukan Penyemprotan Disinfektan di 39 Ribu Titik. Available at: https://metro.tempo.co/read/1337405/covid19-pmi-lakukan-penyemprotan-disinfektandi-39-ribu-titik (Accessed: 1 May 2020).

Tim Satgas Covid-19 UGM (2020) Protokol Disinfeksi di Tempat Kerja UGM (1). Available at: https://hpu.ugm.ac.id/2020/03/15/tim-satgaskewaspadaan-covid-19-ugm-mengeluarkanprotokol-disinfeksi-tempat-kerja/ (Accessed: 15 March 2020).

Tribunnews (2020) Cegah Virus Corona, Seluruh Kantor Polisi di Indonesia Disemprot Disinfektan, Tribunnews.com. Available at: https://www.tribunnews.com/nasional/2020/0 3/16/cegah-virus-corona-seluruh-kantorpolisi-di-indonesia-disemprot-disinfektan (Accessed: 20 March 2020).

US Environmental Protection Agency (2018) Virkon S. US Environmental Protection Agency (2020) List N: Disinfectants for Use Against SARS-CoV-2. Available at: https://www.epa.gov/pesticideregistration/list-n-disinfectants-use-againstsars-cov-2 (Accessed: 31 March 2020).

Wartaekonomi (2020) 4 Unit Bilik Disinfektan Ditempatkan di Rumah Sakit Darurat Wisma Atlet Kemayoran. Available at: https://www.wartaekonomi.co.id/read278507 /4-unit-bilik-disinfektan-ditempatkan-dirumah-sakit-darurat-wisma-atlet-kemayoran (Accessed: 28 March 2020).

World Health Organization (1994) Phenol Health and Safety Guide. Geneva. Available at: http://apps.who.int/iris/bitstream/10665/3995 8/1/9241510889-eng.pdf.

World Health Organization (2004) Environmental Health Criteria 216: Disinfectants and Disinfectant By-products. Available at: http://www.inchem.org/documents/ehc/ehc/e hc216.htm.

World Health Organization (2020) Coronavirus disease (COVID-2019) situation reports. Available at: https://www.who.int/emergencies/diseases/no vel-coronavirus-2019/situation-reports.

Yuwono, A. (2020) Berikut Rute Penyemprotan Disinfektan Serentak di Kota Mojokerto | Suara Jatim Post, Suara Jatim Post. Available 
at:

https://suarajatimpost.com/read/4032/202003

31/120424/berikut-rute-penyemprotan- disinfektan-serentak-di-kota-mojokerto (Accessed: 23 April 2020). 